UDK: 342.724:297 (497.6) "1941"

DOI: 10.51237/issn.2744-1172.2020.49.167

Izvorni naučni rad

Primljen: 27. 4. 2020.

Prihvaćen: 8. 10. 2020.

\title{
Adnan Jahić
}

Filozofski fakultet Univerziteta u Tuzli

Tuzla, Bosna i Hercegovina

adnan.jahic67@gmail.com

\section{Muslimanske rezolucije 1941. $\mathrm{U}$ povodu 80 godina od njihovog potpisivanja}

Apstrakt: Osamdeset godina od njihove pojave, muslimanske rezolucije iz 1941. godine ne prestaju da privlače pažnju kako profesionalnih historičara, tako i šire akademske i društvene javnosti. Dok su starija literatura i publicistika promovirale uglavnom tipska, izvankontekstualna i naglašeno afirmativna gledanja na njihov sadržaj, novija kritička historiografija je postavila više pitanja o stvarnom smislu, značenju i dometima ovih važnih historijskih dokumenata. $U$ ovom radu autor nastoji rasvijetliti širu pozadinu nastanka rezolucija, analizira njihov sadržaj, propituje vjerodostojnost i održivost nekih njihovih tvrdnji i ocjena, bavi se izrečenim i prešućenim u njihovim porukama, te oslikava prijepore i kontroverze koji su pratili pojavu muslimanskih rezolucija do današnjeg vremena.

Ključne riječi: muslimanske rezolucije, muslimani, NDH, ustaše, zločini, pravo, pravda

Abstract: Eighty years since their appearance, the Muslim Resolutions of 1941 have not ceased to attract the attention of both professional historians and the wider academic and social public. While some older literature and publicist writing have promoted mostly typical, extra-contextual and emphatically 
affirmative views on their content, the recent critical historiography has raised many questions about the real substance, meaning and scope of these important historical documents. In this paper, the author seeks to shed light on the broader background of the resolutions, analyzes their content, makes questions about the credibility and sustainability of some of their claims and assesments, deals with the told and unspoken matters in their messages, and portrays the contested views and controversies that have been following the appearance of the Muslim resolutions to the present day.

Keywords: the Muslim resolutions, Bosnian Muslims, NDH, Ustashas, crimes, law, justice

\section{Uvod. Zašto je šutio Kulenović?}

Desetak godina nakon Drugog svjetskog rata, Muhamed Pilav, jedan od dvojice muslimana u predratnoj ustaškoj emigraciji, dao je u Američkom hrvatskom glasniku svoju ocjenu držanja prvaka bivše Jugoslavenske muslimanske organizacije (JMO) u prvim mjesecima Nezavisne Države Hrvatske (NDH). Kritičar predratne politike Spahine stranke Pilav zamjerio je rukovodstvu bivše JMO sa dr. Džafer-begom Kulenovićem na čelu što nije našla za shodno da u danima okupacije zađe u narod i obavijesti ga o međunarodnoj situaciji te pripremi za predstojeće događaje. To je dovelo do toga, pisao je, da niko nije bio toliko osakaćen i izranjavan kao muslimani Bosne i Hercegovine, „zahvaljujući upravo dr. Džaferu“. Osuđujući ustašku državu, autor je naveo da je Kulenović, na pitanje većine članova Centralnog odbora JMO zašto je bez konsultiranja ušao u ustašku vladu, odgovorio: „To sam učinio na svoju ruku i u svoje ime." Takvim svojim postupkom i izjavom, zaključio je Pilav, Kulenović se definitivno odvojio od muslimanskog naroda, čiji je stav prema ustaškoj politici jasno došao do izražaja kroz rezoluciju cjelokupne ilmije i najuglednijih muslimana Bosne i Hercegovine. ${ }^{1}$

${ }^{1}$ Prema: Hrvatski državni arhiv (dalje: HDA), Zagreb, Služba državne sigurnosti Republičkog sekretarijata unutarnjih poslova Socijalističke Republike Hrvatske (dalje: SDS 
Slična zapažanja iznio je i Pilavov savremenik Muhamed Hadžijahić. On je u svom ratnom spisu 1944. godine zabilježio da je Kulenovićev dolazak iz Simovićeve u Pavelićevu vladu 7. novembra 1941. zadao bosanskim muslimanima „strahovit udarac“, kako na domaćem, tako i na međunarodnom planu. Kulenović je to učinio bez obzira na činjenicu što su muslimanski politički prvaci na svom zasjedanju u Doboju zaključili da mu nije mjesto u hrvatskoj vladi, neovisno o pritiscima sa ustaške strane. $^{2}$

Makar su pojedini detalji u gornjim navodima teško provjerljivi, iznesene ocjene i zapažanja dolazile su od dobro upućenih posmatrača ratne zbilje i političke stvarnosti u NDH. Dr. Mehmed Alajbegović, u dva navrata ministar u Vladi NDH, u svom poslijeratnom zatvorskom spisu naveo je da je Paveliću pošlo za rukom uvesti u Vladu Džafera Kulenovića „radi privlačenja Muslimana“, a kada je to postigao, „pustio ga je po strani“, dok su Hakija Hadžić, Alija Šuljak i istomišljenici harangirali Muslimane i radili aktivno za ustaški pokret. Kulenović je imao ured „bez ugleda i posla“, pa prema tome i bez utjecaja, a stvarni potpredsjednik Vlade bio je Vjekoslav Vrančić. Kulenović nije učinio ništa povodom brojnih inicijativa prema Zagrebu da se zaustavi zločinačka politika ustaša u Bosni; odgovarajući kritičarima kako u Vladi predstavlja „samo sebe“, nije odstupao sa svog položaja, „premda se krvavo kolo u Bosni i Hercegovini vrtilo dalje“. ${ }^{3}$

Posljedica Kulenovićevog ulaska u Vladu bila je kompromitacija nekada najjače stranke bosanskih muslimana - Bošnjaka - u očima običnog svijeta i brojnih stradalnika. Bugarski ambasador u NDH Jordan

RSUP SRH), HR-HDA-1561, 010.0.7. Uprava državne bezbjednosti NR Hrvatske Upravi državne bezbjednosti Državnog sekretarijata za unutrašnje poslove FNRJ Beograd. Datum: 18. 7. 1956.

${ }^{2}$ Muhamed Hadžijahić, Posebnost Bosne i Hercegovine i stradanja Muslimana. Rukopis dostavljen savezničkim snagama 1944 (Sarajevo: Centar za bosansko-muslimanske studije, 1991), 37-38.

${ }^{3}$ HDA, SDS RSUP SRH, HR-HDA-1561, 004.2. O bosansko-hercegovačkim muslimanima - Elaborat Alajbegović dr. Mehmeda, 7. 
Mečkarov izvijestio je samo dan nakon Kulenovićevog imenovanja za potpredsjednika Vlade o primjetnom hlađenju muslimana prema Zagrebu, ${ }^{4}$ koje je, očito, imalo u pozadini raznorodne uzroke i poticaje, od favoriziranja katolika nauštrb muslimana do uvlačenja muslimana u pogubnu kampanju protiv „grko-istočnjaka“. Od kraja 1941. Kulenović je personificirao oportunističku i neproduktivnu struju bošnjačke elite koju su napadali kako protivnici, tako i pristaše NDH, svi iz svojih razloga. Jedan kritičar, koji je smatrao pogubnim insistiranje na muslimanskom partikularizmu u hrvatskoj državi, napao je "naše najistaknutije ljude“ da se nisu ni za korak pomakli od "metoda predratne politike“. Još uvijek se zanose mišlju da je najbolje „držati neki neodređeni stav, pa za svaki slučaj da se ima pristupa i u jedan i u drugi tabor“. Upozorio je muslimane, naročito one koji su odgovorni za njihovu sudbinu, „da sadašnja zbivanja nisu parlamentarna natezanja oko sastava vlade i političkih kombinacija i koalicija“, već „povjesni i sudbonosni događaji“ koji od muslimana traže da se jasno opredijele za jednu ili drugu stranu. Autor je, očigledno, glavninu muslimana na pozicijama u NDH smatrao „slabim Hrvatima“ i šićardžijama koje ne zanima sudbina običnog muslimanskog svijeta, već samo „vjerski aršini i ključevi“ preko kojih si teže ugrabiti „masnije položaje“ i sigurnost u zavjetrini ratne neizvjesnosti. ${ }^{5}$

Premda bi se za Džafer-bega Kulenovića teško moglo reći da je držao „neki neodređeni stav“, ni on ni njegovi stranački saradnici po zauzimanju pozicija u vlastima NDH nisu bili naročito vidljivi u javnom životu ustaške države. Kulenović nije ostavljao traga bilo kakve aktivnosti u prilog zaštiti prava svojih sunarodnjaka. No, njegovo je prisustvo u Vladi NDH svejedno poslužilo jugoslavenskoj izbjegličkoj vladi u

\footnotetext{
${ }^{4}$ Nada Kisić Kolanović, Muslimani i hrvatski nacionalizam 1941. - 1945 (Zagreb: Školska knjiga - Hrvatski institut za povijest, 2009), 158.

${ }^{5}$ Gazi Husrev-begova biblioteka (dalje: GHB), Sarajevo, Zbirka rasutih dokumenata i arhivalija na bosanskom jeziku (dalje: ZRDA), A-810/B-3. Autor je skriven iza pseudonima Mujezin. Oglašavao se u nekoliko navrata opširnim analizama vojno-političke situacije tokom 1943. godine. Pripadao je, čini se, sve užem sloju Bošnjaka koji su bili na poziciji bezuslovne lojalnosti Trećem Reichu i NDH.
} 
donošenju negativnih ocjena o držanju Bošnjaka u okupiranoj Jugoslaviji. Povodom Kulenovićevog ulaska u Vladu NDH ministar Branko Čubrilović je na londonskom radiju rekao da će se nakon rata postaviti pitanje „da li će muslimani uopšte moći da sarađuju kao braća u obnovljenoj, velikoj i slobodnoj državi“, jer su oni, makar bili i mirni posmatrači, „krivci i sukrivci mučenja srpskog naroda“. ${ }^{6}$ Pouzdanik dr. Juraja Krnjevića Stjepan Gaži, koji je radio u jugoslavenskom konzulatu u Ženevi, pisao je u jednom izvještaju od 4. decembra 1941. kako su se Muslimani odmah nakon Aprilskog rata „proglasili Hrvatima“ i iza toga otpočeli sa zvjerstvima kako protiv Srba u Bosni, tako i protiv Hrvata komunista u Hrvatskoj, „a da kod toga nikog nisu pitali za legitimaciju“. Pečat ovom pravcu dao je postupak Džafera Kulenovića koji je postao potpredsjednik ustaške vlade „i može se reći da je to jedina politička sila koja stvarno postoji i koja drži Pavelića, jer se dobro zna broj pravih Ustaša “7 I dok su jugoslavenski emigrantski krugovi, temeljem Kulenovićevog ulaska u Vladu NDH, širili u javnosti savezničkih zemalja izrazito negativnu sliku o držanju Bošnjaka i njihove elite u ustaškoj državi, odgovorna lica u zemlji su se suočavala sa haotičnim prilikama u društvu i tražila od svog političkog vođe da preuzetu funkciju iskoristi kako bi se obuzdalo nasilje i prekinule patnje običnih ljudi. „Ti si, dragi Džafere“, pisao je reisul-ulema Spaho Kulenoviću, „ulazeći u vladu u ovim sudbonosnim danima ponio veliku odgovornost prema narodu, pa Ti je dužnost da tražiš izlaza iz ove nepodnošljive situacije. Molim Te stoga, da na najmjerodavnijim mjestima sve ovo izneseš i tražiš, da se počinjene pogreške [hrvatskih upravnih i vojnih vlasti] odmah isprave, te da se učini sve što treba, kako se one više

\footnotetext{
${ }^{6}$ Prema: Zlatko Hasanbegović, Jugoslavenska muslimanska organizacija 1929. - 1941. (u ratu i revoluciji 1941. - 1945.) (Zagreb: Bošnjačka nacionalna zajednica za Grad Zagreb i Zagrebačku županiju - Institut društvenih znanosti Ivo Pilar - Medžlis Islamske zajednice Zagreb, 2012), 759-760.

${ }^{7}$ Ljubo Boban, Hrvatska u arhivima izbjegličke vlade 1941-1943. Izvještaji informatora o prilikama u Hrvatskoj (Zagreb: Globus, 1985), 41.
} 
ne bi ponavljale. ${ }^{\text {88 }}$ Kulenović nije poduzimao ništa, ${ }^{9}$ pa je mnogima bilo jasno da se moraju tražiti zaobilazni putevi kako bi se zaustavilo nasilje i spriječile nove narodne nesreće.

\section{Kritike i osude}

Četrnaestog augusta 1941, isti dan kada je Džafer-beg Kulenović u Zagrebu izjavio da je bivša JMO već od prvog dana NDH uključena u ustaški pokret, ${ }^{10}$ u Sarajevu je Skupština Organizacije ilmije NDH „El-Hidaje“ izglasala rezoluciju kojom je, biranim riječima, pozvala ustašku vlast da zavede punu zakonsku sigurnost svih žitelja NDH. Oglašavanje visoke uleme, koja je i u Kraljevini Jugoslaviji imala aktivnu društvenu ulogu, podsjećalo je na predstavke reisa Čauševića i njegovih muftija koji su se žalili novim vlastima nakon Velikog rata na pljačke i ubijanja muslimana - popunjavajući politički vakuum nastao ratnom pometenošću muslimanskih stranačkih organizacija. Makar je rezolucija bila objavljena samo u njenom službenom glasilu, vodstvo „El-Hidaje“ sa Mehmedom ef. Handžićem na čelu po svoj prilici je smatralo da je nastupio trenutak kada je potrebno zauzeti se za muslimanski živalj, s obzirom na to da su politički prvaci ostali nijemi i pasivni, a neki i aktivno podržavali režim u njegovoj politici terora i represije. No, „El-Hidajina“ ulema nipošto nije bila jedini faktor u bošnjačkom društvu koji je kritički gledao na unutrašnju zbilju NDH 1941. godine. Uznemirujuće prilike u lokalnim zajednicama prisi-

\footnotetext{
${ }^{8}$ Historijski arhiv Sarajevo (dalje: HAS), Sarajevo, Zbirka Fehim Spaho (dalje: FS), SF-800. Pismo Fehima Spahe Džaferu Kulenoviću od 5. veljače 1942.

${ }^{9} \mathrm{U}$ septembru 1944. godine jedan pouzdanik iz Zagreba zabilježio je u svom izvještaju: „Dr. Džaferbeg Kulenović gotovo i nema pristaša među muslimanima Bosne i Hercegovine. Ovo se pripisuje njegovoj nedjelatnosti na položaju podpredsjednika vlade, a k tome još i okolnost, da je do sada uvijek - po mišljenju muslimana - uzpješno spriečavao svaki dobronamjerni pokušaj državne vlade koji je išao za sređivanje prilika u Bosni i Hercegovini. Dr. Džaferbeg Kulenović je među muslimanima omražen napose zbog toga, što je spriečio da se provede u djelo ustav Islamske Vjerske Zajednice, koji ustav je sastavljen od priznatih stručnjaka svećenstva i šeriatskih sudaca." Vidjeti: Vojni arhiv (dalje: VA), Beograd, Nezavisna Država Hrvatska (dalje: NDH), kut. 153c, fasc. 4, dok. 14.

${ }^{10}$ Hrvatski narod, 15. kolovoza 1941, 1.
} 
ljavale su zabrinute prvake da reagiraju i traže lijeka postojećim nevoljama, a nerijetko i upiru prstom u konkretne krivce. Tako se Imamat džemata u Gornjem Vakufu požalio krajem maja 1941. na samovolju lokalnih ustaša katolika koji su, kako su naveli, nakon što su uzurpirali sve pozicije u gra$\mathrm{du}$, zauzeli prema muslimanima isti onakav stav kakav bi zauzeli prema pravoslavnim, „kada bi ih kod nas bilo“. ${ }^{11} \mathrm{U}$ junu 1941. prijedorski imam Derviš ef. Bibić zaputio se u Sarajevo reisu Spahi sa pismom grupe uglednih Prijedorčana koji su tražili od svoga vjerskog vodstva da „u muslimanskom interesu“ pozove na prekid nasilnih konverzija na katoličanstvo i osiguranje vjerske slobode za pravoslavno stanovništvo. ${ }^{12} \mathrm{U}$ septembru 1941. džematski imam u Ljubuškom obavijestio je reisa da su bez ikakve procedure otpušteni iz službe stalni radnici u Duhanskoj stanici u Ljubuškom: Abdulah Orman, Mustafa Kadragić, Hazim Ćerić, Hasan Osmić i Reško Hrnjičević. ${ }^{13}$ Nezadovoljstvo su ispoljavale i pristaše novog režima, razočarane držanjem ustaša, časnika i ljudi na funkcijama, u kritičnim trenucima po sigurnost mjesta. Trojica „Hrvata građana Gračanice“ obavijestila su poglavnika Pavelića 17. septembra 1941. o držanju čelnih ljudi grada i kotara prilikom četničkog napada na Gračanicu 23. augusta 1941. Teretili su ih da su svojim bijegom iz grada i kukavičkim držanjem ostavili na cjedilu „mirni i staloženi narod Gračanice“ koji je napušten od svojih prvaka morao dočekati četnike. Četnici su, srećom, brzo bili odbijeni - zahvaljujući energičnoj intervenciji „naše drage vojske“. ${ }^{14}$ Jedan razočarani

${ }^{11}$ GHB, Arhiv Islamske zajednice (dalje: AIZ), Ulema-medžlis (dalje: UM), 1-2864/1941. Unutar: UM, 2-304-1941.

${ }^{12}$ Tomislav Dulić, Utopias of Nation. Local Mass Killing in Bosnia and Herzegovina, 1941-42 (Uppsala: Uppsala University Library, 2005), 229.

${ }^{13}$ Adnan Jahić, Vrijeme izazova. Bošnjaci u prvoj polovini XX stoljeća (Zagreb - Sarajevo: Bošnjačka nacionalna zajednica za Grad Zagreb i Zagrebačku županiju - Bošnjački institut - Fondacija Adila Zulfikarpašića, 2014), 338.

${ }^{14}$ HDA, Ministarstvo unutarnjih poslova Nezavisne Države Hrvatske (dalje: MUP NDH), HR-HDA-223, kut. 141, 47565. U predstavci su terećena sljedeća lica: ustaški logornik Gračaničkog kotara Franjo Taborski, kotarski pristav i zamjenik kotarskog predstojnika Franjo Šajkaš, načelnik općine Gračanica Hifzo Hifziefendić, predstojnik poreznog ureda u Gračanici Josip Trkman i kotarski školski nadzornik Anto Zidarić. Predstavku su potpisali: željeznički činovnik Ratimir I. Gadža, trgovac Ibrahim Širbegović i bilježnik Salih Džaferović. 
pristaša Hakije Hadžića i Alije Šuljka pisao je vojskovođi Kvaterniku 15. oktobra 1941. o obimu sabotaže koja je prethodila uništenju muslimanskih sela Bilećkog kotara i oštro napao političku i vojnu vlast Bileće da su izdale narod i državu i omogućile „četnicima“ da pobiju nedužni muslimanski živalj. Naveo je da su muslimanski prvaci Bileće molili zapovjednika mjesta satnika Branka Nališa da odredi jednu satniju vojnika koja bi patrolirala noću oko Bileće, ali da im je satnik odgovorio da vojske ne dā, rekavši „da [se] Poljska nije isturila na granicu, ne bi rat izgubila“. Bojnik Jagić skinuo je za vrijeme četničkog napada na Bileću znakove časničkog dostojanstva, sakrio se u podrum, a svoju gospođu sklonio iz vojarne u kuću poznatog četnika Lučića u čaršiji. Sav narod tvrdi da su glavni krivci pokolja u Bilećkom kotaru ubrzo bili nagrađeni, uključujući kotarskog predstojnika Marka Šakića, koji je dobio sedmu grupu i premještaj za kotarskog predstojnika u Sarajevu. Kada je odlazio u Sarajevo, oproštajno veče priredili su mu većinom Srbi, „a do njega je sjedila žena odmetnutog četnika učitelja Kokolja koji je zapovijedao jednom četničkom bandom i baš vršio ove pokolje“. Autor izvještaja, koji je službeno bio ovlašten od ministra udružbe da ode u Trebinje i Bileću i organizira izmještanje tamošnjih stradalnika u Tuzlu, zaključio je da bi spomenute vojne i civilne upravitelje Bileće trebalo pitati zašto, kada je već izvršen napad na Berkoviće i Divin, nisu evakuirali žene i djecu iz Općine Plane u utvrđeni logor u Bileći, zašto su ravnodušno gledali kako četničke bande vrše pokolje i zauzimaju ostale općine, „, zašto su dali 500 metaka na 1.000 seljačkih pušaka u općini Plane“. Potužio se da su četnici u Bilećkom kotaru vršili najbestijalnije zločine. „Žene su skidali gole i na cestama ih klali, svu djecu koja im je pala šaka poklali su a mnogo žive djece pobacali u najdublje jame. " ${ }^{15}$

${ }^{15}$ Institut za historiju u Sarajevu (IHS), Sarajevo, Arhivska građa (AG), kut. 65/1941-45, 14. Prijepis pisma vojskovođi. Tuzla, 15. X 1941. Vidjeti o ustaničkim zločinima u Bilećkom kotaru u: „Izvještaj Uglješe Danilovića Tempu“, Vojnoistorijski glasnik, br. 4 (1951): 179182. Također vidjeti: Spomenica poginulim Bilećanima u NOR i revoluciji (Bileća: Opštinski odbor SUBNOR-a Bileće, 1983), XXIV; Branko Popadić, „Na prostoru Stoca i Bileće“, u: Hercegovina u NOB, 2, ur. Sveto Kovačević (Beograd: Vojnoizdavački i novinski centar Beograd - Istorijski arhiv Hercegovine - Mostar, 1986), 631-650; Tahir Pervan, Nad jamom 


\section{Pismo Fehima Spahe}

Naročito aktivan $\mathrm{u}$ ispoljavanju nezadovoljstva i osudama postupaka pojedinih vojnih i političkih zvaničnika bio je reisul-ulema Fehim Spaho. Suprotno kasnijim stereotipima da je bio neosjetljiv prema tuđim nevoljama, ${ }^{16}$ brojne obavijesti nedvojbeno pokazuju da vjerski poglavica muslimana nije štedio truda u pokušajima da zaštiti svoje sunarodnjake i smanji patnje običnih ljudi, ne samo muslimana nego i pripadnika drugih vjera. ${ }^{17}$ On je, dakako, glavnu brigu ispoljavao prema muslimanima, naročito od vremena kada je, kako se čini, postao svjestan uzaludnosti zauzimanja za pravoslavni i jevrejski živalj u NDH i kada se suočio sa razmjerima stradanja muslimana u prvim mjesecima ustanka. Najotvoreniju kritiku haotičnog stanja u NDH ispoljio je $\mathrm{u}$ jednom pismu nepoznatom državnom zvaničniku, vjerovatno sredinom septembra 1941. godine, koje, zbog njegovih indikativnih navoda, zavređuje da bude podrobnije predstavljeno. U njemu Spaho podsjeća na ranije pismo koje je 8. juna 1941. poslao Slavku Kvaterniku, na koje mu vojskovođa nije odgovorio, a u kojem je reis prenio žalbe u pogledu sljedećeg: komadanja Bosne razgraničenjem velikih župa, postavljanja isključivo katolika kao povjerenika u sarajevskim sudovima i državnim odvjetništvima, popunjavanja istaknutih mjesta u općinama Sarajevskog i Mostarskog kotara samo katolicima te primanja u željeznički tečaj u Sarajevu 41 katolika i svega 9 muslimana. Konstatirao je da su muslimani imali povoljniji procenat u „beogradskoj saobraćajnoj školi“. Dalje je iznio različite prigovore, od primoravanja muslimanske djece u Trebinju da idu u privatno dječije zabavište časnih sestara, nespojivost čega sa šerijatom je iznio i poglavniku, do teških psovki i vrijeđanja muslimana od strane ustaša katolika. Naveo je da su na više mjesta, poput Gornje Tuzle, Gračanice i Sarajeva, vršeni pretresi po muslimanskim kućama, bez dužnog obzira prema vjerskim običajima muslimana. Ustaško

(Sarajevo: Safe House, 2010), 72-81. Usporediti: GHB, ZRDA, A-810/B. Odbor narodnog spasa (dalje: ONS), III knjiga. Poglavlje „Četnički zulumi“ [Bileća].

${ }^{16}$ Enver Redžić, Bosna i Hercegovina u Drugom svjetskom ratu (Sarajevo: OKO, 1998), 320.

${ }^{17}$ Za ilustraciju vidjeti: HAS, FS, SF-694; HAS, FS, SF-698; HAS, FS, SF-745. 
povjereništvo za Bosnu i Hercegovinu, naveo je, zanijekalo je da su ustaše igdje istupile protiv muslimana, ${ }^{18}$ premda su u svim slučajevima bili uznemiravani samo muslimani i muslimansko ženskinje. Iznio je tvrdnje o nejednakom tretmanu Jevreja koji su prešli na islam i Jevreja koji su prešli na katoličanstvo te dodao da se u Budoželju kod Visokog prijetilo džematskom imamu da će biti ubijen „ako bude dalje prevodio grko-istočnjake na islam“. ${ }^{19}$

Glavne reisove žalbe odnosile su se na držanje vojnih zvaničnika kada su odmetnici napali sela i gradove. Nakon stradanja muslimanskih žitelja Avtovca i Mulja kod Gacka vojne vlasti su povele istragu, potvrdile da je izvještaj Imamata u Avtovcu istinit i tek dostavile reisu rezultat istrage, bez ikakvog zaključka o daljnjoj zaštiti naroda. Strahujući od novih pokolja, kod Spahe je 30. augusta 1941. došla deputacija Gačana koja ga je obavijestila da je „četnička djelatnost ponovo počela“, pa je reis vojskovođi poslao novo pismo u kojem je zatražio da se narodu dā oružje i municija da se može sam braniti, kao i da se u Gacku i okolini pojača vojna posada te u nju uvrste vojnici iz brdskih krajeva, vješti tamošnjem terenu, ,jer sadanja vojska, koja je došla iz slavonskih ravnica, ne poznaje ovog terena i teško se bori s četnicima“. Tražio je i da državna vlast pomogne ili eventualno sama povede evakuaciju žena, djece i staraca u koji drugi kraj, zajedno s ljetinom koja se upravo sabire, „jer prijeti velika opasnost, da četnici provale baš radi ove ljetine, da bi je prigrabili sebi i omogućili svoju ishranu“. Vojskovođa opet ništa

\footnotetext{
${ }^{18}$ Nakon što mu je reis Spaho uputio nekoliko pritužbi na ponašanje ustaša prema muslimanima, ustaški povjerenik za Bosnu i Hercegovinu Jure Francetić, podsjećajući reisa na poznate stavove poglavnika o muslimanima, odgovorio mu je: „Ne odgovara istini, da se sa ustaške strane niti u jednom slučaju istupilo kao protiv muslimana, nego naprotiv je istina, da su muslimani iako pristaše raznih bivših režima sa strane Ustaških dužnostnika gdje je to ikako bilo moguće postavljeni na vodeća mjesta. “Vidjeti: GHB, AIZ, UM, 1-2864/1941. Unutar: UM, 2-304-1941. Dopis Francetića Spahi od 26. lipnja 1941.

${ }^{19} \mathrm{Za}$ odnos hrvatske vlasti prema ovim Spahinim žalbama vidjeti: HDA, MUP NDH, HR-HDA-223, kut. 32, 921. Izvještaj Velikog župana Velike župe Lašva i Glaž dr. Nikole Tusuna Ministarstvu unutarnjih poslova NDH od 5. rujna 1941. godine. Sve su pritužbe ocijenjene izmišljenim.
} 
nije odgovorio, „niti imam kakva daljeg izvještaja šta je učinjeno“. Reis je optužio za izdaju zapovjednika vojne jedinice kojoj je bila povjerena zaštita Berkovića, na putu između Stoca i Bileće. Dok se mnogi građani i za mnogo manje krivice, pa i nevini, stavljaju pred prijeki sud, ovaj je časnik predan redovnom vojnom sudu u Mostaru, gdje se govori da bi mogao biti riješen bilo kakve krivnje. Na reisovu pritužbu protiv dotičnog časnika sa nadležnog mjesta stigao mu je samo odgovor da je u pitanju „jugoslavenski oficir“. Sljedeći navod ilustrira koliko je muslimanski vjerski starješina imao informacija o kobnim zbivanjima izbjeglog stanovništva iz Bileće i okoline:

„Svi muslimani iz kotara Bileća, ukoliko nijesu pobijeni, njih oko 3.500 hiljade na broju, izbjegli su. Sve njihove kuće su popaljene, a cijeli imetak opljačkan. Oni se nemaju kuda vratiti, a i ne misle da se vraćaju. Jedna njihova deputacija otišla je u Zagreb, da traži, da im se da neko mjesto u Bosni, kuda bi se mogli preseliti. Za 700 njihovih izbjeglica, koji su imali biti dopraćeni u Stolac, a tamo nijesu stigli, uopće se ne zna šta je s njima." ${ }^{20}$

$\mathrm{Da}$ je reis ovoj predstavci dao nešto općenitiji ton i da je usvojena od strane nadležne vjerske skupštine ili nekog drugog foruma, vrlo vjerovatno bi je historijska nauka zabilježila kao Spahinu rezoluciju. Ona je donijela nekoliko karakterističnih pritužbi muslimanskih rezolucija koje je potpisala i poslala na različite adrese muslimanska elita u jesen 1941. Premda je isticao individualnu odgovornost, neizravno je Spaho napao cijeli sistem - da je gradio poredak po mjeri Hrvata katolika, ispoljavajući krajnju neosjetljivost prema potrebama, pravima i osjećajima muslimana. No, Spahu je od potpisnika rezolucija dijelila ključna razlika: nigdje nije spomenuo nasilje nad Srbima. Iz njegove ostavštine

\footnotetext{
${ }^{20}$ GHB, ZRDA, A-814/B. Prijepis sačuvanog reisul-uleminog pisma je, nažalost, nepotpun. Čini se da mu nedostaje prva strana iz koje bi se moglo vidjeti ko je zvaničnik kojem je reis pisao. Na zadnjoj strani nema ni potpisa ni datuma niti bilo kakve oznake. Moguće je da je upućeno potpredsjedniku Vlade NDH Osman-begu Kulenoviću, jer se reis njemu obraćao povodom drugih problema i nevolja.
} 
je vidljivo, naveli smo, da Spaho nipošto nije indiferentno posmatrao nepravde prema jevrejskom i srpskom narodu. On je, međutim, kao vjerski poglavica, očito smatrao da mu je dužnost pokušati zaustaviti, ili barem ublažiti patnje svojih suvjernika koji su došli na udar protumuslimanski nastrojenih srpskih ustanika, a to je, vjerovao je, mogao postići jedino u okvirima redovne komunikacije sa organima ustaške države, makar ta komunikacija bila impregnirana tonovima ljutnje, kritike i osude. U takvoj komunikaciji za pretpostaviti je da je držao neproduktivnim izazivati zvaničnike NDH upiranjem prstom u nepravde i zločine nad pravoslavcima i temeljem toga umanjivati izglede u pogledu očekivane pomoći muslimanima. Spaho nije vjerovao u svrsishodnost potpisivanja rezolucija, ${ }^{21}$ ostajući privržen individualnom zagovoru kao, po njegovom sudu, jedinom produktivnom sredstvu borbe za narodni interes. Nije promijenio ovaj pristup, neovisno o upozorenju iznijetom u njegovom pismu državnom tajniku NDH Asimu Ugljenu, da je pojava rezolucija u uslovima tonjenja NDH u duboki ratni haos sasvim razumljiva i da bi ponašanje nadležnog ministarstva prema ličnosti reisul-uleme i njega moglo otjerati u „rezolucionare“.22

\section{Rezolucije. Osuda zločina ili bijeg od odgovornosti?}

Spahina predstavka bila je kudikamo oštrija i konkretnija u odnosu na skupštinsku rezoluciju „El-Hidaje“ donijetu 14. augusta 1941. To je i razumljivo, ima li se u vidu da je „El-Hidajina“ rezolucija bila javni dokument, a „El-Hidajino“ vodstvo u prvim mjesecima NDH prožeto entuzijazmom $\mathrm{u}$ pogledu donošenja novog ustava Islamske vjerske zajednice u skladu sa težnjama udruženja. U takvim okolnostima „El-Hidajina“ rezolucija više je ličila na novi akt lojalnosti i podrške NDH nego na deklaraciju uperenu protiv njene politike. Na nekoliko mjesta je izražena privrženost hrvatskoj državnoj i nacionalnoj ideji, čak je insistirano da se „svakako Sandžak

${ }^{21}$ Hasanbegović, Jugoslavenska muslimanska organizacija, 754-755.

${ }^{22}$ Kisić Kolanović, Muslimani i hrvatski nacionalizam, 196. 
uključi u okvir Nezavisne Države Hrvatske“. No, pomnije čitanje jasno razotkriva tri glavna motiva i razloga koja su potaknula autore rezolucije na njeno pisanje: nastojanje da država što prije ozakoni novi ustav IVZ po mjeri visoke uleme, očiglednu neravnopravnost katolika i muslimana u NDH i zabrinjavajuće stanje sigurnosti u zemlji. Za to stanje nije prozvana hrvatska država, nego su samo pozvane državne vlasti „da što prije zakonski zavedu sigurnost u svim krajevima ne dozvoljavajući da se što bilo čini na svoju ruku kako ne bi nevini ljudi stradali“. Ovo bi se moglo shvatiti kao želja - nerealna i neutemeljena - da redovna vlast suzbije maligni utjecaj ustaškog pokreta, čije je destruktivno djelovanje moralo biti poznato „El-Hidaji“. Autori rezolucije, međutim, ni na jednom mjestu nisu spomenuli divljačko bezakonje nad Srbima, nego samo nevine muslimanske žrtve, „koje nedužne padoše u nemirima, koji se ovih dana mjestimično događaju“. Također su smatrali umjesnim osuditi samo one pojedine muslimane „koji su na svoju ruku sa svoje strane eventualno napravili kakav bilo ispad i učinili kakvo nasilje“. Ovim su brojni zločini ustaša svedeni na sporadične nerede i ispade do kojih su doveli „neodgovorni elementi i neodgojeni pojedinci“, na svoju ruku, izvan sistema, koji je brižljivo amnestiran od bilo kakve odgovornosti. „El-Hidaje“ ove pojedince nije nazvala „divljim ustašama“, ali je jasno naglasila da ljagu ovih ljudi odbija od sebe i od svih muslimana. Poput reisa Čauševića nakon Sarajevskog atentata 1914. godine, autori rezolucije pozvali su sve muslimane u Bosni i Hercegovini da se u duhu visokih uputa islama, „i u interesu države“, strogo klone svakog nedjela. ${ }^{23}$

Premda je veza ove rezolucije sa dolazećim muslimanskim rezolucijama bila jedva vidljiva, Muhamed Hadžijahić je ispravno ocijenio da se ona može smatrati njihovim začetkom, naročito sarajevske rezolucije, ${ }^{24}$ iza koje su ponovo stali istaknuti članovi „El-Hidaje“. No, taj joj status nije donijela osuda zločina, već zahtjev za uspostavom reda i sigurnosti,

${ }^{23}$ El-Hidaje V, br. 1 (1941-2): 27-29.

${ }^{24}$ Muhamed Hadžijahić, „Muslimanske rezolucije iz 1941. godine“, u: 1941. u istoriji naroda Bosne i Hercegovine (Sarajevo: Veselin Masleša, 1973), 275. 
kao i osiguranjem ravnopravnosti katolika i muslimana u javnom životu NDH. „El-Hidaje“ je, sasvim razumljivo, u prvom planu imala bosanski muslimanski živalj; premda je zahtjev za vladavinom prava i zakona imao univerzalno značenje, glavni motiv je poticao iz posljedica njihove dosljedne primjene, a to su sigurnost i zaštita muslimana. Prema navodima Kasima ef. Dobrače, idejni začetnik sarajevske rezolucije Mehmed ef. Handžić rekao je svom bliskom prijatelju kojeg je pozvao kući na sijelo: „Noćas smo na sielu samo nas dvojica. Na ovom sielu treba da padne tekst jedne izjave ili rezolucije, koju će podpisati muslimanski predstavnici i bar jedan dio građanstva. Niko nema prava da nas uništava, a niti da nas gura političkim pravcem, koji će imati za posljedicu naše stradanje. Muslimani imaju pravo da to javno i otvoreno reknu. “25 Dio „[...] da nas uništava“ izvjesno se odnosio na srpske ustanike, a „da nas gura političkim pravcem“ očito na hrvatske ustaše - Handžić je, kako izgleda, vrlo brzo postao svjestan položaja muslimana između čekića i nakovnja, savršenog sistema manipulacije, žrtve i uništenja. Dva mjeseca nakon „El-Hidajine“ rezolucije, u kojim su se dogodili zločini u Berkovićima, na Trusini, u Kulen-Vakufu, a ustaše vršile bespoštedna „čišćenja“ u selima koja su dovođena u vezu sa pobunjeničkom akcijom, inicijatori sarajevske rezolucije, poznate također kao „ramazanska“, smatrali su da moraju biti mnogo konkretniji u navođenju odgovornih za postojeći haos i mjerama koje treba poduzeti da se zaštite životi i prava običnih ljudi. Tako su vinovnici zločina nad nedužnim muslimanskim civilima označeni kao neodgovorni elementi i pobunjeni Srbi - nije upotrijebljen od vlasti i novinara redovno korišten termin „četnici“, odnosno „četničko-komunističke bande“. Jedna poslijeratna izjava sugerira da su krugovi bliski KPJ u Sarajevu imali određenog utjecaja na stilizaciju nekih formulacija u rezoluciji. ${ }^{26}$ Odgovornost za pobunjeničku akciju, za razli-

${ }^{25}$ Kasim Dobrača, „Rad Handžića u El-Hidaji i njegov družtveni rad uobće“, El-Hidaje VIII, br. 2-3 (1944): 86.

${ }^{26}$ Dr. Zaim Šarac, utjecajni antifašista i predsjednik podzemnog Narodnooslobodilačkog odbora u okupiranom Sarajevu, nakon Drugog svjetskog rata ugledni ministar i narodni poslanik te član Ustavnog suda, potpisao je u Sarajevu 10. maja 1964. 
ku od augustovske rezolucije „El-Hidajine“ skupštine, sada je neizravno pripisana vladajućem režimu, a izravno „pojedinim vlastima“ u NDH koje su, kako je navedeno, poduzimale i poduzimaju poteze koji još više izazivaju „oštre reakcije pobunjenika“, posljedica čega su nova stradanja bijednog i nezaštićenog stanovništva. Ovim je ponovljena kritika koju su isticali mnogi domobranski i oružnički zapovjednici, zgranuti nekontroliranim nasiljem ustaša. „Umjesto da se pristupilo otvorenoj borbi sa pobunjenicima t. j. sa onima koji su se digli na ustanak“, stajalo je u izvještaju zapovjednika 4. oružničke pukovnije o stanju u istočnoj Bosni i Hercegovini, „pristupilo se uništavanju njihovih sela i ubijanju njihovih porodica, pljački i tome slično, što je imalo za posljedicu, da je otpor bivao sve žešći, pa su se pobunjenicima priključili i oni, koji na to nikad nisu ni pomišljali. “27 Mnogobrojne ljudske žrtve, oteti i uništeni imeci, paljenje sela, prekid mirnog života seljaka koji su se u masama upućivali ka gradovima, siročad koja su se potucala tražeći hranu i zaštitu - sve je to potaklo autore rezolucije da istaknu „da ovo niesu žrtve koje su rodoljubi dužni podnieti za svoju grudu“, nego je riječ o općem neredu „koji se sve više širi i vodi propasti Hrvata muslimana Bosne i Hercegovine“. Ključno zapažanje je tek slijedilo:

izjavu kojom je jamčio moralno-političku korektnost bivšeg člana Glavnog odbora „El-Hidaje“ i poslijeratnog političkog zatvorenika Kasima ef. Dobrače. U toj je izjavi priznao da je nastojao preko Dobrače utjecati na sadržaj sarajevske rezolucije prije potpisivanja. „Dok je ova rezolucija bila još u vidu koncepta, prigovorio sam Vam [Dobrači] da bi trebalo određene izraze i osude, koji bi mogli biti nezgodni za partizane, brisati odnosno ispraviti. Lično ste se složili, ali ste me kasnije obavijestili, da Vam to nije uspjelo $u$ cijelosti [kurziv: A. J.] izvršiti zbog opiranja drugih, koji su Rezoluciju trebali potpisati, - pošto su se ti izrazi odnosili na neke elemente koji nisu bili pod komandom i vlasti partizana. “Šarac je dodao da se ovom rezolucijom u osnovi željelo „osuditi zločine fašista“ i da je u njihovim razgovorima Dobrača uvijek osuđivao regrutovanje i učestvovanje „naših ljudi“ u raznim fašističkim organizacijama i vojnim formacijama, naročito u 13. brdskoj SS diviziji. Vidjeti: Adnan Jahić, „Bilješke o djelovanju bosanskohercegovačke uleme u Drugom svjetskom ratu“, Historijska misao, br. 1 (2015): 181-184.

${ }^{27}$ Zbornik dokumenata i podataka o Narodnooslobodilačkom ratu jugoslovenskih naroda, tom IV, knjiga 1 (Beograd: Vojnoistorijski institut JNA, 1951), dokument br. 245, 546-547. 
„Sve ovo podrmava svako uvjerenje u sigurnost i daje povoda da se na temelju samoga toka činjenica, a nešto možda i propagandom neodgovornih elemenata, stvara u širokim i neupućenim slojevima uvjerenje, da je ovo sistem, koji se smišljeno provodi.“

Dio „sistema“ je prepoznat i u tvrdnjama „mnogih katolika“ koji su prebacivali odgovornost za sva nedjela na muslimane i tumačili „sve događaje“ kao međusobno razračunavanje između muslimana i pravoslavaca. Potpisnici rezolucije nisu problematizirali udio proustaške muslimanske elite $\mathrm{u}$,izazivanju“ pravoslavaca te su sve muslimane vršitelje zlodjela okarakterizirali kao „ološ i kriminalne tipove“ kojih ima u svakoj zajednici. Konstatirano je „da ni oni nisu to od sebe činili dok im nije dato oružje, uniforma, ovlašćenje, a često put i naredbe“. Ovo su navodili, primijetimo, i potpisnici drugih rezolucija, ali i pojedine vojne vlasti koje su pisale o mobilizaciji muslimana u akcijama protiv „grko-istočnjaka“. Kada je zapovjednik oružničke postaje u Žirovcu u augustu 1941. spriječio novi upad naoružane muslimanske mase i nove zločine nad mirnim pravoslavnim seljacima na području Dvora na Uni, koji su „čišćeni“ uprkos činjenici što se radilo o kotaru koji nije bio proglašen pobunjeničkim krajem, morao se suočiti sa neugodnim pitanjem velikog župana iz Bihaća po čijem je naređenju zaustavio upad muslimana na područje njegove postaje, kao i prijetnjom da će ga kao „nehrvata“ po svaku cijenu izbaciti iz državne službe. ${ }^{28}$ Ipak, makar su zločini nedvojbeno zahtijevali naoru-

${ }^{28}$ Izvještaj zapovjednika oružničke postaje Žirovac prenijet je u izvještaju Zapovjedničtva 3. hrvatske oružničke pukovnije od 25. augusta 1941. U njemu je navedeno kako je 22. augusta u oko 8 sati ujutro oko 2.000 muslimana [sic] pod vodstvom zapovjednika oružničke postaje Ravnice (sjeverno od Bosanske Krupe) upalo na područje susjedne postaje Žirovac te počelo hvatati ljude bez obzira na spol, klati ih i pljačkati sve redom što im je došlo do ruke. Nakon ubijanja i pustošenja ova je masa povela sa sobom oko 300 sve samih žena i sitne djece i sve ih poklala na području Ravnica. Kotarski predstojnik u Dvoru na Uni odmah je naložio zapovjedniku oružničke postaje Žirovac da svim silama zaustavi svaki rad samovoljnih masa, što je dovelo do višesatnog oružanog okršaja oružnika i civila sa jedne i druge strane Une, nakon kojeg su Bosanci bili protjerani. Dan poslije ponovo je muslimanska masa, sada bez vodstva oružnika, navalila na područje Žirovca, ali je kotarski predstojnik zatražio pomoć od velikog župana iz Petrinje te su muslimanski civili potpuno razbijeni; oko 50 napadača je razoružano, oduzete su im opljačkane stvari, a potom su 
žanje, ovlašćenje i naredbu, kojih nije moglo biti bez nositelja političke moći u NDH, uglavnom ustaša katolika, potpisnici rezolucije nisu mogli imati saznanja dostatna za tvrdnju s kojom su smjelo istupili - da muslimani „ni u kojem slučaju“ ne snose odgovornost za počinjena zlodjela niti su im bili inicijatori, osim ako se pod muslimani ne misli na cijeli narod ili zajednicu. Ponovljena je tvrdnja koju su navodili mnogi savremenici - i koja nije mogla biti izmišljena - da su razna nedjela u Bosni činili ljudi pod fesovima, dozivajući se pritom muslimanskim imenima, iz čega su potpisnici rezolucije izvukli zaključak da je u pozadini bila skrivena namjera ljudi iz sjene da se zločin neraskidivo veže za muslimanski element. Da muslimani nikome nisu mislili i spremali nikakvo zlo dokaz je, istakli su, njihova prošlost za turskog vremena, kada su bili jedini gospodari, tolerirali sve vjere i nikome nisu zuluma činili, ali i činjenica da su muslimani - bivši jugoslavenski vojnici - odmah nakon Aprilskog rata 1941. predali vojno oružje novoj vlasti.

Iako je glavni cilj bio zaustaviti nasilje koje je prijetilo novim stradanjima muslimana, u zahtjevima upućenim svim odgovornim faktorima

odvedeni u Glinu. „Ovom prilikom pomenuta vojska uhitila je i zapovjednika oružničke postaje Ravnice narednika Pilingera Marina, istoga razoružala i također odvela sa sobom u Glinu da tamo objasni po čijoj je zapovjedi predvodio ovu masu i dozvolio im da rade na svoju ruku što su htjeli." Vidjeti: Arhiv Bosne i Hercegovine (dalje: ABiH), Sarajevo, Zbirka NOR-a (dalje: NOR), Neprijateljska dokumenta (dalje: ND) 1941. Kompilacija izvještaja Zapovjedničtva 3. hrvatske oružničke pukovnije, 6-7. Nije se radilo o 2.000, već o 200 naoružanih bosanskih muslimana, kako se vidi iz izvještaja Oružničke postaje Dvor na Uni od 24. augusta 1941. Usporediti: Zločini na jugoslovenskim prostorima u Prvom i Drugom svetskom ratu. Zbornik dokumenata, tom I, Zločini Nezavisne Države Hrvatske 1941-1945, ur. Slavko Vukčević (Beograd: Vojnoistorijski institut, 1993), dok. 244, 585-586; Ljuban Đurić, Banijski partizanski odredi 41-45 (Beograd: Vojnoizdavački i novinski centar, 1988), 50-51. Prema Đuriću, naoružani muslimani pod vodstvom Pilingera bili su ustaše iz Cazina i Bužima koji su, zajedno sa ustašama muslimanima iz Vrnograča, već izvršili mnoge zločine nad srpskim življem Cazinske krajine. Đuro Zatezalo je zabilježio da su 22. augusta 1941. ustaše, oružnici, domobrani i „civili Muslimani-ustaše“ upali u srpska sela duž Suve međe iz pravca Bosanske Otoke i Vrnograča te u srpska sela Dvorskog i Glinskog kotara. Hvatali su muškarce, žene i djecu. „Njih 700 zvjerski ubijaju noževima i maljevima u šumi Rastovača, nedaleko [od] Suve međe kraj Gornjeg Žirovca.“ Vidjeti: Đuro Zatezalo, „Razvoj i rad KPJ i organa narodne vlasti. Čerkezovački partizanski odred“, u: Dvor na Uni. Od prijeslavenskog doba do naših dana, knj. 1, ur. Mile Joka (Dvor na Uni: Skupština Općine Dvor na Uni, 1991), 301. 
u državi i muslimanskim vjerskim i političkim predstavnicima potpisnici rezolucije dali su zahtjevu za sigurnost, pravdu i kažnjavanje zločinaca najširi građanski karakter - izričito je naglašeno „bez ma kakvih razlika“, čak je insistirano na punoj vjerskoj trpeljivosti, u državi koja je rušila vjerske objekte, poticala konverzije na katoličanstvo i vršila progone i likvidacije ljudi na vjerskoj osnovi. Nije traženo sudsko gonjenje samo počinitelja zločina nego i onih koji su naređivali zlodjela, pa čak i onih koji su te zločine omogućili. Ključni zahtjev bio je da zakone ubuduće primjenjuju samo redovna vlast i redovna vojska, čime je izravno napadnut ustaški pokret, ne samo divlje ustaše nego i redovne zaklete ustaše uključene u kampanju protiv „grko-istočnjaka“. Iza rezolucije svojim potpisima stali su ugledni članovi vjerskog i društvenog života sarajevskih muslimana: čelni ljudi „El-Hidaje“, članovi Ulema-medžlisa sa izuzetkom Mehmedalije ef. Ćerimovića, direktor vakufa dr. Hazim Muftić, upravitelji islamskih obrazovnih zavoda, predsjednici i sekretari muslimanskih društava, uključujući prvog čovjeka prohrvatske „Narodne uzdanice“ Edhema Mulabdića, političke ličnosti poput Uzeir-age Hadžihasanovića, Hasan-age Nezirhodžića i Edhema Bičakčića, kadije, imami, trgovci, profesori, suplenti i studenti, pa i pojedinci izrazito hrvatske nacionalne orijentacije hafiz Akif Handžić, Hazim Šabanović i Halid Čaušević. ${ }^{29}$

Premda u osnovi vrlo srodna sarajevskoj rezoluciji, predstavka Kotarskog vakufsko-mearifskog povjerenstva u Prijedoru od 22. septembra 1941, iza koje su stali ugledni Prijedorčani, označena je u popratnoj noti zapovjednika Vojne krajine Ministarstvu hrvatskog domobranstva od 6. novembra 1941, za razliku od sarajevske, fočanske ${ }^{30}$ i drugih

${ }^{29}$ GHB, ZRDA, A-810/B. ONS, II knjiga. Sarajevska rezolucija od 12. listopada 1941.

${ }^{30}$ Nažalost, sadržaj ove fočanske rezolucije, koju historiografija nije zabilježila, nije nam poznat. Vjerovatno bi doprinio rasvjetljavanju, u historijskoj nauci još uvijek prilično maglovitih, odnosa u Foči u prvim mjesecima NDH, naročito u kontekstu neutemeljenih tvrdnji da su zločini ustanika i četnika posvuda imali u pozadini ustaška divljanja i likvidacije srpskog stanovništva. Za prilike u Foči od aprila do decembra 1941. usporediti: VA, NDH, kut. 258, fasc. 3, dok. 13; Adil Zulfikarpašić, „Put u Foču. 25. I. 1942. godine“, Godišnjak, br. 4 (1957): 44-55; Vladimir Dedijer, Anton Miletić, Proterivanje Srba sa ognjišta 1941-1944. Svedočanstva (Beograd: Prosveta, 1989), 282-284. 
deklaracija, kao naročito uperena protiv Hrvata katolika. Cilj joj je dokazati zapostavljanje muslimana u korist katolika, „pa su joj svakako inicijatori tzv. Jugomuslimani““31 Ipak, sudeći prema ocjeni jednog ustaškog zvaničnika, ovi „Jugomuslimani“ nipošto nisu bili neka beznačajna manjina u Prijedoru. Muslimani u Prijedoru nisu baš tako siguran element kako se drži. „Čaršijski Muslimani nerijetko gunđaju protiv vlasti i države

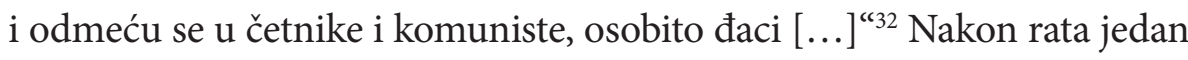
ustaški emigrant doveo je u vezu agilnog hodžu Derviša ef. Bibića sa mjesnom KPJ. Bibić je u džamiji javno tvrdio „da su Islam i Kuran vrlo blizki komunizmu““. ${ }^{33}$ Ovi navodi bacaju svjetlo na činjenicu da u rezoluciji muslimana Prijedora uopće nisu spomenuti ni partizani ni četnici, već isključivo hrvatska vlast i ustaše katolici koji su terećeni da vode politiku diskriminacije muslimana i njihovog konfrontiranja sa pravoslavcima. Potpisnici rezolucije, međutim, predstavili su prijedorske muslimane kao lojalni hrvatski element, koji samo želi ravnopravan tretman u javnom i političkom životu prijedorskog kraja, uključujući priliku da se uključi u upravne strukture i ustaški logor - što mu katolička manjina ne dozvoljava, pod izgovorom da je nepouzdan. Otuda svu vlast u Prijedoru drže katolici i od osnivanja NDH nijedan mještanin musliman nije zaposlen ni u kakvoj službi, „iako je poslije istjerivanja Srba ostalo dovoljno mjesta“. Posljedica takve politike je kulturna i društvena marginalizacija muslimana, uključujući neosnovane optužbe na račun muslimanske mladeži da je inficirana komunizmom, kao i pritiske na prijelaznike na islam da pređu na katoličanstvo. Najteže optužbe potpisnici su iznijeli na račun ustaškog logora koji je, kako su naveli, mobilizirao mjesni muslimanski živalj u krvavim kampanjama protiv pravoslavnog stanovništva:

\footnotetext{
${ }^{31}$ ABiH, NOR, ND 1941, 174/7774.

${ }^{32}$ Navedeno prema: Izudin Čaušević, „Ustaška vlast i teror na Kozari 1941-1942 godine“, u: Kozara u Narodnooslobodilačkoj borbi i socijalističkoj revoluciji (1941-1945). Radovi sa naučnog skupa održanog na Kozari (Mrakovica) 27. i 28. oktobra 1977. godine u okviru proslave Titovih jubileja i 35-godišnjice kozarske epopeje, ur. Nikola Babić (Prijedor: Nacionalni park „Kozara“, 1980), 115.

${ }^{33}$ Safet Jaskić, Srbokomunistički zločin nad Bosnom, reprint izdanje, (Tuzla: Izdavačko prometno preduzeće „Hamidović“, 2003), 74.
} 
„Za vrijeme pobune u okolini našega kotara bez pitanja ma koga od muslimana naoružao je ovaj logor između ostalih muslimana i najgori muslimanski ološ pa čak i cigane te je ovakove tipove uz suradnju divljih ustaša upotrebljavao za ubijanje mirnog građanskog stanovništva grčko-iztočne vjere, a to se poslije radilo u cilju da se pokaže kako su jedini muslimani zulum činili, i da je jedino katolička crkva jedino sigurno mjesto za zaštitu ovih ljudi od muslimanskog zuluma.

Prikazivanje muslimana u ružnom svjetlu ide tako daleko da pojedine pokretne ustaše katoličke vjere ćak i sudovima privode žene pohapšenih pobunjenika i pokušavaju da svjedoče kako njihovi muževi nisu pobjegli u šumu od 'korektnog ponašanja ustaša već od zuluma muslimana ustaša koji pristaju uz ustaše te pljačkaju i ubijaju bez milostí.

U obližnjoj ispostavi Kozarcu, divlje ustaše, kojima se sada ne može uhvatiti traga, sa naperenim puškama sile muslimane mještane da sjekirama ubijaju pohapšene seljake grčko-iztočne vjere, a poslije se to prikazuje kao likvidiranje nekih starih računa između ovih seljaka i muslimana. Znanjem toga logora i divlje ustaše nose fesove te se stvara zabuna da sve zlo dolazi od muslimana. Čak i ime Tomislava Dizdara nekakvog ustaškog zapovjednika, koji je prvi izdao naredbu za mjesno ubijanje iskorišćava se da se prikaže kao da je taj zapovjednik musliman.

Siromašni mještani muslimani stavljaju se pod prijeki sud, osuđuju na smrt i strijeljaju zato što su navodno iz vilica poubijanih ljudi išćupali nekoliko zlatnih zuba, dok se nitko i ne osvrće na nestanak milionskih imetaka koji su usred bijelog dana i to za vrijeme pobune raznešeni od drugih, o čemu je otišla pritužba na nadležno mjesto. “34

Dostupni izvori govore $\mathrm{u}$ prilog mnogih tvrdnji iznesenih u prijedorskoj rezoluciji. Jedan njemački izvor navodi da su početkom juna 1941. ustaše poslane iz Ljubuškog, po nalogu velikog župana Ljubomira Kvaternika, pobile mnogobrojne pravoslavce, među kojima i žene i djecu, u

\footnotetext{
${ }^{34}$ ABiH, NOR, ND 1941, 174/7774. Deklaracija Muslimana iz Prijedora.
} 
Sanskom Mostu, Ključu, Bosanskom Petrovcu i Prijedoru. ${ }^{35}$ U izvještaju pukovnika Dolanjskog navodi se da je u Prijedoru, pored domaćih ustaša, uzelo učešća u klanjima i nešto hercegovačkih ustaša („pokretne ustaše“), koje su po nalogu vlade došle iz Hercegovine na područje Sanskog Mosta, Ključa, Bosanskog Petrovca i Prijedora. Pored njih, tvrdi Dolanjski, u Prijedoru je bio i izvjestan broj zagrebačkih ustaša, ali se ne zna pod čijom su komandom došli. ${ }^{36} \mathrm{U}$ julu i augustu 1941. ustaša Pinto, preobraćeni Židov koji je postao katolički bogoslov, poklao je zajedno sa mjesnim i zagrebačkim ustašama u roku od 13 dana oko 1.500 ljudi u Prijedoru. ${ }^{37}$

Ipak, koliko je vjerodostojna tvrdnja da su svi zločinci muslimani tek po nalogu i pod pritiskom vodećih ustaša činili zločine nad pravoslavnim življem Prijedora i okolnih mjesta? Potpisnici rezolucije nisu se ogradili od postupaka svojih sunarodnjaka u klanjima tokom ljeta 1941, poput Husejna Mujagića koji je predvodio divlje ustaše na području Kozarca, gdje je sjekirama pobijeno nekoliko stotina „grko-istočnjaka“. ${ }^{38}$ Nisu spomenuli trake za slobodno kretanje koje su, kako bi ${ }^{35}$ Zločini, ur. Vukčević, dok. 372, 971.

${ }^{36}$ Radilo se, kako se navodi u knjizi Vedrane Adamović, o pripadnicima tzv. Kvaternikove garde, koja je u prvim danima NDH položila zakletvu na Sveučilišnom trgu u Zagrebu, a zatim se pod zapovjedništvom pukovnika Mate Čanića zaputila u Bosnu. Bila je stacionirana dijelom u Banjoj Luci, a dijelom na području Prijedora. Zapovjednik u Prijedoru bio je ustaški satnik Slavko Dasović. Prema izvorima na koje se autorica poziva, pripadnici tzv. Kvaternikove garde, oko 120 mladića u dobi između 16 i 20 godina, stigli su u Prijedor 29. jula 1941, uoči masovnog pokolja Srba. Na glavama su imali husarske crvene kapice sa slovom „U“, a zapovjednik im je bio Vjekoslav Dizdar iz Makarske. Dizdar je neposredno rukovodio ubistvima Srba u Prijedoru 1. augusta 1941. Vidjeti: Vedrana Adamović, Godine stradanja 1941/42. NDH i njeni zločini nad srpskim narodom u Prijedoru i okolini 1941/42. (Prilog proučavanju zločina genocida nad srpskim narodom u Potkozarju) (Prijedor: Muzej Kozare, 2018), 29-31, 81, 84, 96. U prijedorskoj rezoluciji, kako smo vidjeli, zapovjednik je naveden kao Tomislav Dizdar. Tzv. Kvaternikova garda bila je, čini se, sastavni dio bosanskohercegovačkog odjela hrvatske vojske, obrazovanog sa zadatkom da preuzme vlast i formira vojne jedinice na teritoriji Bosne i Hercegovine. Vidjeti: Milan Vukmanović, „Okupacija i uspostavljanje ustaške vlasti na području Bosanske krajine i Srednje Bosne u prvim mjesecima 1941. godine", u: Oblasna partijska savjetovanja na Šehitlucima u junu i julu 1941. u razvoju ustanka u Bosanskoj krajini (Banja Luka: Institut za istoriju u Banjaluci, 1981), 71-72.

${ }^{37}$ HDA, Odjeljenje zaštite naroda za Hrvatsku (OZNA), HR-HDA-1491, 4.1.9.

${ }^{38}$ Čaušević, „Ustaška vlast i teror na Kozari“, 107. 
se razlikovali od pravoslavaca, nosili muslimani i katolici u Prijedoru za vrijeme Ilindanskog pokolja. ${ }^{39} \mathrm{U}$ prijedorskom kraju, kao i drugdje, ustaše nalogodavci su uvukli u pokolje dio lokalne fukare i ološa primamljivim obećanjima pljačke i bogaćenja, kako sugerira i jedan detalj iz Memoranduma Srpske pravoslavne crkve vojnom zapovjedniku okupirane Srbije Heinrichu Dankelmannu. U njemu se navodi da su u Prijedoru formirana specijalna odjeljenja sastavljena „od muslimana i cigana“ koja su odvlačila leševe poubijanih Srba uz nagradu da slobodno pljačkaju žrtve. „Oni su ih skidali nage, a čak su žrtvama skidali zlatne zube te tovarili po sedam do osam leševa na kola i odvozili do ogromnih jama u blizini groblja koje su nastale od avionskih bombi te bacali ih i zatrpavali, a delimično bacali u Sanu. “40 Bivši kotarski predstojnik u Dvoru na Uni dr. Marin Bučan svjedočio je nakon rata da su masovna klanja Srba u kotarevima Bosanske krajine, uključujući Prijedor, uslijedila nakon naređenja koja su došla iz Ministarstva unutarnjih poslova $\mathrm{NDH}$, a da su imovinu pobijenih i opljačkanih međusobno dijelili kao nagradu neposredni izvršioci likvidacija. ${ }^{41}$ Mada je obim učešća jedne zajednice u počinjenim zločinima veoma teško ustanoviti, a prodrijeti u glavne razloge i motive gotovo nemoguće, razložno je pretpostaviti da su i u Prijedorskom kotaru zavladale iste one društveno-psihološke prilike, obilježene atmosferom neizvjesnosti, straha i izbjegavanja da se javno djeluje, koje su pogodovale mobilizaciji socijalnog taloga posvuda u NDH - ljudi koji su živjeli od danas do sutra, u čestom sukobu sa zakonom, primitivnih pogleda na život i društvo, spremnih iskoristiti pogodan trenutak i staviti se na raspolaganje novim moćnicima, koji su zauzvrat nudili obilno zadovoljavanje njihovih „potreba“.

Potpisnici prijedorske rezolucije nisu dali konkretne prijedloge šta uraditi kako bi se postojeće stanje promijenilo, samo su zamolili istaknute

\footnotetext{
${ }^{39}$ Adamović, Godine stradanja, 90-92.

${ }^{40}$ Zločini, ur. Vukčević, dok. 249, 612-613.

${ }^{41}$ Milan Bulajić, Ustaški zločini genocida i suđenje Andriji Artukoviću 1986. godine, I (Beograd: Izdavačka radna organizacija „Rad“, 1988), 736-737.
} 
muslimane da dopru do poglavnika i drugih visokih zvaničnika kako bi se opisanim pojavama stalo na put, „i to sa najvišeg mjesta“. Konkretniji su u svojim zahtjevima bili potpisnici muslimanske rezolucije u Bosanskoj Dubici, povodom nesnošljivog stanja terora i anarhije uperenog protiv mirnog života stanovnika ovog graničnog bosanskog kotara. Usto, za razliku od rezolucije u Prijedoru, autori rezolucije u Bosanskoj Dubici smatrali su potrebnim otvoreno osuditi zločine nad srpskim življem koji, navođeno je, nisu imali nikakve veze sa odmetanjem i pobunom. Glavnu odgovornost za ova zlodjela snosi ustaški logor u Bosanskoj Dubici, koji potpuno zanemaruje naredbe i intencije državne i kotarske vlasti, ali i težnje i želje uznemirenih mještana Bosanske Dubice. Već prvi koraci samozvanih ustaša, koji su bili hizmećari svih mogućih političkih struja u bivšoj Jugoslaviji, pokazali su kakvo će nesretno stanje nastati u Dubičkom kotaru:

„Odmah se je počelo sa progonom, pljačkom i ubijanjem nedužnih i mirnih građana i seljaka pravoslavne vjere, koji su se pred tim neviđenim nasiljem počeli sklanjati po šumama i laćati se oružja.

Tako je nastalo ovo nesnosno i očajno stanje u kojem gine na hiljade naših sinova, žena i djece, u kojem se divljačkim načinima uništavaju sela i gradovi i plodovi teških napora, žrtava i rada, okrvavljene nam Herceg-Bosne.

I ako je Poglavnikovom Odredbom zavedeno redovno stanje u Nezavisnoj Državi Hrvatskoj, članovi ustaškog logora u našem mjestu produžavaju sa nasilničkim metodama, a u stalnoj oprečnosti sa kotarskom vlašću, koja je vodeći računa o željama većine poštenog, mirnog i radinog stanovništva, nastojala da zavede red i mir i stvori povjerenje u redovne vlasti ove države.“

Potpisnici rezolucije u Bosanskoj Dubici naglasili su da „svjesno i pošteno građanstvo“ želi da se prestane sa progonom, paljenjem, klanjem i pljačkanjem, da se zaustave sva nasilja prema pravoslavnom stanovništvu koje mirno živi i radi kod svojih domova, a ustaški dužno- 
snici u Bosanskoj Dubici ih nazivaju neprijateljima ove države. Uz želju za mir, rad i bezbrižnu sutrašnjicu, dubički uglednici su iznijeli četiri konkretna zahtjeva - podudarna zahtjevima rezolucije sarajevske elite: da se svi ustaški dužnosnici i oružani članovi ustaškog logora otpuste iz službe i privedu zasluženoj kazni, da se u Bosansku Dubicu uopće ne upućuju ustaške satnije, već samo domobrani, da se istinitost iznesenih tvrdnji podvrgne strogoj i opsežnoj provjeri i da se povede računa o zahtjevima rezolucije kako ovaj kraj ne bi sustigla sudbina Kulen-Vakufa i drugih mjesta. Navedeno je da potpisnici imaju i moralno pravo da istupe sa rezolucijom. „Naši sinovi i braća bore se na istočnom frontu, služe i bore se u našem domobranstvu, rade u rudnicima i fabrikama Njemačke, naša sela gore, naši napori i patnje su neviđene, mi imamo moralno pravo kad tražimo da se naš glas čuje. “42

Iako su potpisnici muslimanskih rezolucija u prvi plan stavljali uspostavu reda i zakonitosti i prestanak nasilja nad nedužnim stanovništvom bez obzira na vjeru i porijeklo, nesporno je u njihovoj pozadini, pored nezadovoljstva mjerama represije koje su vodile stradanju muslimana, bio i narastajući interesni sraz između muslimanske i katoličke elite, uslovljen očiglednom katoličkom dominacijom na koju su gradski muslimanski krugovi reagirali karakterističnom osjetljivošću i pritužbama. Razlog reagiranja, barem u nekim sredinama, nije bio samo briga za ravnopravnost njihovih suvjernika nego i težnja da se ne ostane uskraćen za „pripadajuće“ beneficije i privilegije. U žalbi „delegata banjalučkih muslimana“ upućenoj 9. augusta 1941. velikom županu Velike župe Sana i Luka Ladislavu vitezu Alemanu iznesene su pritužbe na račun novog banjalučkog gradonačelnika Rudolfa Ertla - vrlo slične pritužbama potpisnika prijedorske deklaracije, ali uz protezanje nezadovoljstva na „prikraćenost“ muslimana prilikom likvidacije židovskih i pravoslavnih

${ }^{42}$ HDA, Zbirka mikrofilmova gradiva iz inozemnih arhiva koje se odnosi na Hrvatsku (ZMGIA-H), HR-HDA-1450, D-2179, MF59, 447. Rezolucija Bos. Dubičkih Muslimana. Prilog dopisu Zapovjedničtva 3. oružničke pukovnije vojnim i redarstvenim vlastima u Zagrebu. Datum: 30. siječanj 1942. Iz priloženog dokumenta ne vide se datum, adresat i okolnosti donošenja rezolucije. 
radnji, „jer su muslimanima dane samo dvije a katolicima sve ostale radnje“. Kao ni u drugim predstavkama i rezolucijama, nije osuđena otimačina jevrejske i srpske imovine, niti otpuštanje jevrejskih i srpskih namještenika, ali jeste otpuštanje iz službe 48 muslimana, kao i umirovljenje pet muslimana, „od kojih je većina mogla još da radi i posluži općini““ ${ }^{43}$ Ipak, mjesec dana od sarajevske rezolucije, banjalučki muslimanski uglednici istupili su sa rezolucijom uperenom isključivo protiv ustaške politike diskriminacije, terora i zločina prema nepoćudnim elementima, ostavljajući u drugom planu pitanje ravnopravnosti i prava muslimana u komunalnim okvirima. Banjalučka rezolucija od 12. novembra 1941, koju su katolički kritičari nazvali pamfletom i podvalom čiji je cilj amnestirati muslimane od bilo kakve odgovornosti za nerede i zločine koji su se desili, bila je sadržajno najbogatija i najdalekosežnija po iznesenim tvrdnjama i optužbama i nije ostavljala nikakve sumnje da je teretila ne tek skupinu neobuzdanih ustaša, nego cijeli sistem ustaške države, sa izuzetkom, dakako, samog poglavnika koji je posredstvom muslimanskih članova Vlade trebao biti „upoznat“ šta se događa u nesretnim kotarevima „Hrvatske krajine“.

U Bosanskoj krajini su se desili neki od najstravičnijih zločina u okupiranoj Jugoslaviji, pa su autori rezolucije smatrali neophodnim odrediti se prema tim događajima i objasniti ulogu muslimanskog elementa u njima. Oslikana je, izrazito otvoreno, sva okrutnost ustaškog režima, usmjerenog na bespomoćni pravoslavni živalj i njegove prvake.

„Ubijanje svećenika i drugih prvaka bez suda i presude, strijeljanje i mrcvarenje u gomilama često posve nevinih ljudi i žena pa i djece, gonjenje u masama od kuće i iz postelje čitavih porodica s rokom od jedan do dva časa za spremanje te njihovo deportiranje u nepoznate krajeve, prisvajanje i pljačkanje njihove imovine, rušenje bogomolja, često njihovim vlastitim rukama, siljenja na prelazak u rimokatoličku vjeru, sve su to činjenice koje su zaprepastile svakog čestitog čovjeka i koje su na nas muslimane ovih krajeva djelovale najneugodnije.“

${ }^{43}$ Zločini, ur. Vukčević, dok. 191, 462. 
Istaknuto je da muslimani nikada nisu očekivali, a kamoli željeli „ovakve metode rada i upravljanja u našim krajevima“. Iako s rezervom, autori su te postupke nazvali politikom, koja je rezultirala katastrofalnim posljedicama; vjerska snošljivost, ranije na visini, došla je pod znak pitanja, a bratstvo dva dijela naroda, katoličkog i muslimanskog, „na putu je da doživi potpuni slom“. Ovo zapažanje iznosili su i pojedini vojni zvaničnici iz Banje Luke, ali su negirali isključivu odgovornost katolika za takvo stanje. Rascjep između muslimana i katolika je „skoro gotova stvar“. Impresionirani radom i uspjesima „četnika“, muslimani se pobojavaju za sebe, pa se dešavalo da uzimaju u zaštitu „grko-istočnjake“. U razgovoru oni sebe potpuno odvajaju od Hrvata, pa kažu: „Mi muslimani... a vi Hrvati.“ Zbog loših materijalnih prilika izvjestan broj muslimana ispoljava simpatije prema „komunistima i grko-istočnjacima“, a u izbjegličkim krugovima u Beogradu neki muslimani šire letke u kojima za svu nesreću Bosne krive Hrvate, navodeći da su Hrvati u fesovima vršili nasilja nad Srbima. ${ }^{44}$ Za ovo udaljavanje, međutim, autori banjalučke rezolucije prvenstveno su krivili „neke ustaše i druge odgovorne i neodgovorne faktore“, ali i jedan dio katoličkog svećenstva koji, istaknuto je, beskrupulozno iskorištava novo političko stanje. Njihovi postupci jasno pokazuju da u stvarnom životu NDH pripadnici islama nemaju jednaka prava:

„Propaganda za pokrštavanje je uzela takvog maha, da podsjeća na špansku inkviziciju. Pod njenim pritiskom i uz toleriranje javnih organa izvršena su pokatoličavanja hrišćana u masama. I tako su oni, kojima se do tada poricala svaka građanska vrijednost i nacionalna srodnost, postali i građanski punopravni i nacionalno Hrvati, samo zato što su formalno primili katoličku vjeru. Ravnopravnost Islama izticana često pisanim slovima i mnogim izjavama s najviših mjesta, dovodi se često u pitanje u životu i praksi. Prelazak na Islam, koji mi nismo propagirali, nije nikada pružao onu zaštitu kao prelazak na

\footnotetext{
${ }^{44}$ Arhiv Tuzlanskog kantona (dalje: ATKT), Tuzla, Radnički pokret i NOB u sjeveroistočnoj Bosni 1920. - 1945. [digitalizirana arhivska građa] (RP-NOB), 3-OJ66-41. Doglasno izvješče Zapovjedničtva II. Domobranskog zbora za vrieme od 16.-31. prosinca 1941. godine.
} 
katoličku vjeru. Mnogi intelektualci takav pokušaj su platili životom, kao što je to bio slučaj u Travniku. Čuju se često i pogrdne pjesme, od strane ustaša, koje vrijeđaju vjerski osjećaj muslimana i proriće im se ista sudbina kao i hrišćanima. “45

Jedan dio ustaške vojnice, i ne samo oni „divlji“, vršio je teške ispade i atake na hrišćane, ali i na pojedine muslimane. Tako je u Banjoj Luci, nasred avlije gradske bolnice, u po bijela dana, ustaša Josip Babić usmrtio nevinog seoskog hodžu Edhema ef. Hodžića. „I što je najžalosnije, ne zna se ni danas, da li je zločinac uopće uhapšen, a kamo li kažnjen ekzemplarno, kako je to tražilo i traži svo banjalučko i ostalo muslimansko stanovništvo." Slučaj usmrćenog hodže je plastično oslikao društveno-psihološku zbilju i lahkoću oduzimanja ljudskog života u NDH. Šta se desilo? Dvadesetosmogodišnji imam iz Kozarca Edhem ef. Hodžić, teškog mentalnog stanja, doveden je 30. septembra 1941. u banjalučku bolnicu na liječenje. Ubrzo je izašao u dvorište bolnice i počeo vikati na sav glas: „Živio Kralj Petar!“ Na te riječi jedan ustaša je „izvadio svoj samokres i ispalio na Hadžića [sic] dva hitca prostrijeljivši mu glavu i na mjestu ga ubio“" ${ }^{46}$ Dan poslije, na dženazi ubijenom imamu, održao je kraći govor čuveni banjalučki političar i javni radnik ing. Suljaga Salihagić, koji je pred okupljenom masom izjavio da je Hodžiću „um potamnio od straha" usljed prizora jednog groznog zločina. Dodao je da oni koji bi trebali „da nas uzmu u zaštitu i da nas brane od napadaja, oni isti su ubili ovoga jadnoga čovjeka na jedan upravo zvjerski način“.

${ }^{45}$ „Slučaj u Travniku“ odnosi se na ubistvo građevinskog inženjera Stanka Turudije iz Travnika. Prema Mustafi Mulaliću, ustaše su ga ubile jer je, umjesto na katoličku vjeru, prešao na islam, pod obrazloženjem da je i islam državna vjera u NDH. Pogledati: Adnan Jahić, „Zbivanja u Bosni i Hercegovini 1941. godine prema Hronici Mustafe Mulalića“, u: Bosna i Hercegovina 1941: novi pogledi, ur. Husnija Kamberović (Sarajevo: Institut za istoriju, 2012), 177-178. Isto je naveo i reis Spaho u svom pismu dr. Osman-begu Kulenoviću od 22. septembra 1941. Vidjeti: GHB, AIZ, Povjerljiva arhivska građa, POV-5, 1193/1941. Dragi Osman-beže!

${ }^{46} \mathrm{ABiH}, \mathrm{NOR}, \mathrm{ND}$ 1941. Kompilacija izvještaja Zapovjedničtva 3. hrvatske oružničke pukovnije, 10. Izvještaj zapovjednika redarstvene straže u Banjoj Luci Stjepana Tereta od 1. listopada 1941. 
Na to su se prolomili povici negodovanja okupljenih građana protiv ubice i ustaša. ${ }^{47}$ Drugi vidovi napada na muslimane, istakli su potpisnici, čine terećenja za komunizam; zbog pokojeg komuniste sa muslimanskim imenom progone se i hapse i oni koji nikada nisu bili komunisti, dok mnogi katolici, koji su bili poznati kao komunisti, ne samo da se prikrivaju nego se često i nagrađuju raznim položajima i sinekurama. No, potpisnike rezolucije naročito je ispunilo negodovanjem što su oni elementi, „koji su prouzrokovali ovaj ustanak“, uvukli u svoju protusrpsku akciju i dio muslimanskog ološa - što oni žale i osuđuju:

„Mi znamo dosta primjera gdje su ustaše pristupile klanju i ubijanju hrišćana pod fesovima na glavi. To je bilo u Bosanskom Novom, gdje su četiri kamiona ustaša došla iz prijeka pod fesovima, udružili se s muslimanskim ološem i izvršili klanje hrišćana u masama. Isto se desilo i u Bosanskoj Kostajnici gdje je na isti način i za jedan dan poklano 862 hrišćanina. I u Kulen Vakufu su to isto radili i tu se naročito istakao Miroslav Matijević ustaša iz Vrtoča. Tu je poklano okolo 950 hrišćana, što je dalo povoda za osvetu četnika od 6 rujna, kada je Kulen Vakuf zapaljen i gdje je platilo glavom 1.365 muslimana (ljudi, žena i djece). Mi znamo slučajeva gdje su neke ustaše katolici udarali na hrišćane s povicima: 'Udri Mujo! Drži Huso! Ne daj tamo Meho ...' i slično. Mi znamo i takvih slučajeva gdje se je šaputalo hrišćanima kako ih ubijamo i koljemo mi 'balije' da ih tako istrijebimo. Da smo mi htjeli trijebiti, ubijati i prevjeravati Srbe i druge, mi smo to mogli lakše učiniti prije nekoliko stotina godina kada smo imali više vlasti nego danas i kada se je mogao takav postupak lakše pravdati nego danas.“

I nakon što je izazvan sukob između muslimana i hrišćana, muslimanski vojnici su pozvani da guše taj sukob, da nastave ubijati Srbe i oni njih, „pa da se tako međusobno satiremo i iztrebljujemo ne znajući kada će to prestati ni kakvim će poslijedicama uroditi“. Tako će najvišu cijenu opet plaćati nedužni muslimanski civili, dok se vinovnici nereda povlače

\footnotetext{
${ }^{47}$ GHB, ZRDA, A-810/B. ONS, II knjiga. Govor koji je „izazvan od naroda“ održao ing.
} Suljaga Salihagić na dženazi rahmetli Edhema ef. Hodžića 1. X 1941. godine. 
u pozadinu, paradiraju u uniformama i zabavljaju se pljačkom srpske i jevrejske imovine. Na kraju rezolucije potpisnici su se pridružili ciljevima i zahtjevima sarajevskih muslimana od 12. oktobra 1941. i zamolili muslimanske predstavnike u Vladi NDH da o svemu izvijeste poglavnika i ulože sav svoj upliv „da se ovome strašnom stanju učini kraj“ ${ }^{48}$ Rezoluciju su potpisali vjerski uglednici, bivši gradonačelnici, šerijatske sudije, učitelji, činovnici, trgovci, zanatlije i drugi viđeniji članovi banjalučkog društva, uključujući gradonačelnika i brata ministra u Vladi NDH Hilmije Bešlagića Hakiju i govornika na dženazi ubijenog imama Suljagu Salihagića.

Preostale tri dostupne rezolucije, mostarska, bijeljinska i tuzlanska, uglavnom su iznosile iste ili slične tvrdnje i pritužbe, uz važnu razliku koja je odvajala bijeljinsku od svih ostalih rezolucija: označavanje svih žitelja Bosne i Hercegovine Bosancima, koji su povijesno formirani kao posebnost u odnosu na Hrvate i Srbe. U mostarskoj rezoluciji su u šest jezgrovitih konstatacija osuđeni svi zločini počinjeni u NDH i izražena želja da se zavede potpuna jednakost, ravnopravnost i zakonitost za sve ljude u NDH, bez obzira na vjersku i narodnu pripadnost - izričito su spomenuti „pravoslavni Srbi“, a ne „grko-istočnjaci“ (koji se pod tim nazivom spominju u bijeljinskoj rezoluciji), što bi se moglo dovesti u vezu sa činjenicom da su neki od istaknutih potpisnika mostarske rezolucije bili pobornici srpske i jugoslavenske nacionalne ideje u bivšoj državi. ${ }^{49}$ Nisu spomenuti ni ustaše, ni ustanici ni komunisti, ali su zato upozorena „braća muslimani“ da dobro razmisle o skrovitim namjerama pojedinaca koji su ili intelektualni začetnici ili egzekutori raznih zlodjela „nad našim sugrađanima“, a koji u svojim krugovima „bez ustezanja

${ }^{48}$ Pri navođenju smo se služili tekstom rezolucije unutar: GHB, ZRDA, A-810/B. ONS, II knjiga. Banjalučka rezolucija od 12. studenog 1941. Izvjesne očigledne greške pri prepisivanju i druge nelogičnosti korigirali smo prema verziji u: HDA, Velika župa Posavje (dalje: VŽP), HR-HDA-254, kut. 3, 148/1942. Kotarski predstojnik u Brčkom velikom županu Velike župe Posavje dr. Vladimiru Saboliću. Rezolucija Muslimana Banje Luke.

${ }^{49}$ Zlatko Hasanbegović, „Muslimanske rezolucije iz 1941. godine. Problem interpretacije“, Bošnjačka pismohrana 12, br. 36-37 (2013): 170. 
to namjenjuju i nama muslimanima “. ${ }^{50}$ Riječ muslimana grada i kotara Bijeljine od 2. decembra 1941. bila je donijeta, kao i tuzlanska rezolucija od 11. decembra 1941, povodom pokolja izvršenog nad nedužnim stanovništvom Koraja 27. novembra $1941 .{ }^{51}$ Bile su najizravniji izraz zabrinutosti muslimanske elite sjeveroistočne Bosne stanjem javne sigurnosti i posljedicama sve intenzivnijeg nasilja po njihove sunarodnjake, nakon što je izostalo oglašavanje povodom terora i deportacija Srba u ustaške logore. Čini se da je donošenje rezolucije u Bijeljini bilo u izvjesnoj vezi i sa sukobom vojnih krugova i utjecajne bijeljinske elite na čelu sa Murat-begom Pašićem, koji je vjerovatno stajao iza rezolucije, jer se upravo kod njega nalazio originalni primjerak sa potpisima. ${ }^{52}$ Njegov istomišljenik veliki župan Velike župe Posavje dr. Vladimir Sabolić tumačio je rezoluciju kao izraz nezadovoljstva bijeljinskih muslimana nebrigom nadležnih vojnih struktura prema njihovoj sigurnosti, no njen sadržaj pokazuje da je glavni cilj bio obuzdati zagovornike odmazde i spriječiti ponavljanje Koraja. Zato su osuđeni postupci „i jednih i drugih neodgovornih lica" te su pozvani i katoličke i muslimanske ustaše i pobunjeni „grkoistočnjaci“ da prestanu sa krvoprolićem i osvetama „koja vode samo našoj obćoj propasti i iztrebljenju“. Tuzlanska rezolucija je bila najdalje od građanskog usmjerenja sarajevske i banjalučke rezolucije: dok su ustaničke akcije nazvane „neredima“ u kojim su stradali prvenstveno muslimani, protusrpska kampanja je opisana tek kao „ispadi“ od strane neodgovornih elemenata. Osnovni cilj rezolucije, koja je zapravo bila pismo „ministru predsjedniku“ Kulenoviću, bila je molba da se zaustave „neredi“, kojim su kumovali „ispadi“, ako ne isključivo vojničkim putem, onda i političkim mjerama, poput pozivanja

\footnotetext{
${ }^{50} \mathrm{ABiH}$, Zemaljska komisija za utvrđivanje zločina okupatora i njihovih pomagača Sarajevo (dalje: ZKURZ), Referati, kut. 7, 82. Rezolucija muslimana grada Mostara.

${ }^{51}$ O pozadini i okolnostima donošenja ovih rezolucija vidjeti: Omer Hamzić, „Podsjećanje na dvije muslimanske rezolucije iz 1941. godine - bijeljinsku i tuzlansku“, Gračanički glasnik, br. 34 (2012): 110-117.

${ }^{52}$ HDA, VŽP, HR-HDA-254, kut. 3, 194/1942. Krilno oružničko zapovjedništvo Tuzla Velikoj župi Posavje - Bosanski Brod. Datum: 14. siječnja 1942.
} 
na odgovornost i javnog kažnjavanja „svih krivaca za nezakonite čine“ ${ }^{53}$ I bijeljinska i tuzlanska rezolucija uslijedile su kada je postalo jasno da su ustaničke akcije već postale ozbiljna prijetnja sigurnosti muslimana sjeveroistočne Bosne.

Iz dostupnih izvora se ne vidi da su ustaške vlasti bile naročito uznemirene pojavom muslimanskih rezolucija, a ni spremne na ozbiljnije represivne mjere protiv njihovih potpisnika. Muhamed Hadžijahić piše da je kod ustaša ovaj put prevladao „hladan razbor i računica“, pa su se ograničili na sitnije represalije prema pojedincima na nižim položajima.${ }^{54}$ Nije potkrijepio svoje navode o reakcijama čelnih ljudi NDH, premda bi tvrdnje o prijetnjama potpisnicima mogle biti vjerodostojne. Manje je vjerodostojna navodna Pavelićeva prijetnja „da će sarajevskim asfaltom prije poteći krv autora rezolucije nego li će se vlada NDH odreći svog programa“, jer bi njena autentičnost podrazumijevala Pavelićevu spremnost da prizna odgovornost ustaša, pa i njega lično, za pojavu i širenje ustanka i postojeći haos u državi. Dostupni izvori govore, kako to i Hadžijahić potvrđuje, da je vladajućim ustaškim krugovima pojava rezolucija bila manifestacija nepouzdanosti muslimanskog elementa koji, smatrali su, još uvijek kalkulira i ne vidi hrvatsku državu kao trajni okvir za svoj život i budućnost. Vlasti, međutim, nisu dozvoljavale da se ta manifestacija razvije u širi društveni kapital nezadovoljnih gradskih elita, pa su suzbijale umnožavanje i rasturanje rezolucija, tretirajući ih kao ilegalni propagandni materijal. ${ }^{55}$ Zašto su izostale ozbiljnije mjere protiv potpisnika? Prije svega jer se radilo o stotinama uglednih i utjecajnih ljudi. Potpisnici su, slično učesnicima muslimanskog autonomnog pokreta dvije godine ranije, istupili kao jaka i organizirana falanga čije bi slamanje zahtijevalo težak i neizvjestan društveni obračun. Paveliću i ustašama nije trebalo otvaranje novog fronta u uslovima širenja pobunjeničke akcije i gubitka gradova i kotareva u istočnoj Bosni.

\footnotetext{
${ }^{53}$ ATKT, Ustaška nadzorna služba (UNS), 5671/64.

${ }^{54}$ Hadžijahić, „Muslimanske rezolucije iz 1941. godine“, 281.

${ }^{55}$ Jahić, Vrijeme izazova, 350.
} 
Dok je ustaški režim, zarad viših državnih interesa, uglavnom ignorirao navode i zahtjeve u rezolucijama, pojedinci su u njima gledali zapanjujuću gomilu podmetanja i kleveta uperenih protiv NDH i njene hrvatske katoličke većine. Katolički banjalučki biskup fra Jozo Garić pisao je predsjedniku Hrvatskog državnog sabora Marku Došenu da su sve muslimanske rezolucije "pamflet pun paklenih kleveta i mržnje proti katoličkoj Crkvi“, kojim muslimani teže da „svoje vlastite grijehe $i$ zločine svale na katolike i da se operu pred Srbima". ${ }^{56}$ Garić je s pravom primijetio da su autori rezolucija propustili navesti koliko je muslimana divljih ustaša sudjelovalo u pokoljima pravoslavaca. On je, međutim, u cijelosti zanemario ključnu ulogu nalogodavaca i izvanbosanskih ustaša katolika te je ustvrdio da su krvoprolića u kotarevima Bosanske krajine izvršili „isključivo muslimani“, a da su neznatna manjina katolika, napose svećenici, „svi od reda“ štitili nevine pravoslavce „prije nego je se među njima pokazao pokret za prelaz na katolicizam“. ${ }^{57}$ Garić je napao muslimane da im nije padalo na pamet da prave rezolucije kada su se nasilja i pokolji događali, nego kada je zastala njemačka ofanziva na Rusiju - strahujući od srpske odmazde. Biskup je dijelom bio u pravu: rezolucije su doista „pravljene“ nakon što su najokrutniji zločini već bili počinjeni. On je, ipak, previđao da je glavni motiv bio osuditi i zaustaviti nasilje koje je prijetilo životima i imovini muslimana. Drugi dio Garićeve tvrdnje je bio bez osnova, jer su sve rezolucije već bile potpisane do zaustavljanja njemačke vojske pred Moskvom, 5. decembra 1941.

Banjalučka rezolucija izazvala je naročito negodovanje među katolicima, što se vidi i po komentaru nepotpisanog kritičara koji je, očigledno,

\footnotetext{
${ }^{56}$ Prema: Jure Krišto, Sukob simbola. Politika, vjere i ideologije u Nezavisnoj Državi Hrvatskoj (Zagreb: Nakladni zavod Globus, 2001), 331. Isticanje: izvorno.

${ }^{57}$ Tvrdnja da su sve zločine nad pravoslavcima 1941. činili muslimani nije bila rijetka među katoličkim krugovima. Prema kazivanju Have Hadžiosmanović, izvjesna sestra Olga, nastavnica u jajačkom klosteru, pričajući djeci o nemilim događajima, izjavila je: „Djeco, ne mojte misliti [sic] da ovaj pokolj vrše katolici, jer je to strogo zabranjeno po našoj vjeri. To sve prave muslimani i od stotinu onih koji vrše pokolj nad Srbima nema po jedan katolik a ostalo su sve muslimani i takvi će biti strijeljani." GHB, AIZ, A-809/B-1. Izvještaj Halima Malkoča, imama iz Jajca.
} 
dobro poznavao društvene prilike u Banjoj Luci i smatrao važnim ukazati na prešućene činjenice u rezoluciji. ${ }^{58} \mathrm{U}$ osvrtu na ovaj „infamni pamflet" odmah je pripisao - čini se osnovano - autorstvo nad rezolucijom ing. Suljagi Salihagiću, istaknutom političaru, publicisti i aktivnom radniku prosrpskog „Gajreta“, tereteći ga da je u Velikom ratu došao kao austrijski šuckor u jedno srbijansko selo i predstavio se nekoj starici kao Srbin muslimanske vjere. Potom je godinama uvjeravao Srbe da je odvajkada bio Srbin, zatim je potkraj Jugoslavije izdao brošuru u kojoj je zagovarao autonomiju Bosne i Hercegovine, ${ }^{59}$ da bi se po formiranju $\mathrm{NDH}$ stavio na čelo banjalučkih muslimana i sada među njima „vodi glavnu riječ“. Teretio je i njegovu suprugu Ifaket-hanumu: da je na sjednici Odbora za proslavu poglavnikovog imendana, pred gradonačelnikom Hakijom Bešlagićem, izjavila da ona uopće nije Hrvatica, „kao što nisu ni drugi Muslimani“. Dodao je da je rekla da su se Muslimani ranije držali Srba „ukoliko su ih trebali“, a sada će se držati Hrvata, „ako im se dade ono što im je obećano sa najvišeg mjesta“. U suprotnom - radit će na svoju ruku! Kritičaru su ovi navodi bili dovoljni da dokuči razloge i pozadinu rezolucije. Ako su gospoda potpisnici, pitao je, sa zabrinutošću gledali šta se sve događalo, šta su učinili da se to spriječi? Kako i kada su reagirali na zlodjela svojih „suplemenjaka“ u cazinskom, ključkom, krupskom, prijedorskom, sanskom i novskom kotaru? Koliko je bilo katolika u Kulen-Vakufu? Je li Matijević mogao sam izvršiti onakav pokolj? Kada već priznaju da je bilo zločinaca i njihove vjere, zašto se onda toliko zauzimaju za taj svoj ološ? Šta su učinili da se

${ }^{58}$ Vidjeti: ABiH, ZKURZ, Referati, kut. 7, 82. „Kratki osvrt na prednji infamni pamflet“. Nažalost, na dokumentu nema ni datuma ni potpisa. Nije isključeno da ga je pisao sam biskup Garić, njegov tajnik fra Kruno Brkić ili neko od njima bliskih katolika.

${ }^{59}$ Riječ je o brošuri Suljage Salihagića pod nazivom Mi bos. herc. muslimani u krilu jugoslovenske zajednice. Kratak politički pogled na našu prošlost od najstarijih vremena do danas. Štampana je i izdana u Banjoj Luci, čini se krajem 1940. godine. U njoj, na stranama 39-40, Salihagić zaista spominje razgovor koji je 1915. vodio sa „jednom ženom“ u selu blizu Kosjerića, ali je cilj razgovora drukčiji od onog koji navodi kritičar, a autor nije došao u Srbiju kao šuckor, već kao pripadnik „Baukumpanije“, graditeljske regimente, kao inženjer u austrijskoj oficirskoj uniformi i sa fesom na glavi. 
sačuva „bratstvo obaju djelova naroda“? Ove ozbiljne primjedbe potpisnicima, ipak, devalviralo je svaljivanje krivice samo na jedan element: autor osvrta sveo je sve pokolje u Bosanskoj krajini na bezakonje divljih ustaša muslimana, a prekrštavanje pravoslavaca na prijelaz iz nužde „da bi se zaštitili od zuluma Muslimana“. „Zašto ne navedu slučajeve propagande koja potsjeća na Špansku inkviziciju? Gdje je pravljen pritisak na pokatoličenje?" Cijela rezolucija pisana je „u podle svrhe“, uključujući zlobno izrabljivanje „jednog nesretnog slučaja“, pogibije hodže u Banjoj Luci. Da u ovoj zemlji vladaju druge prilike, onaj koji je držao govor na grobu „nesretno poginulog“ (Salihagić) sjedio bi sada s onu stranu brave! Kritičar je u tvrdnjama potpisnika banjalučke rezolucije vidio samo hrpu nekonzistentnih navoda i ocjena - nije negirao, ali nije ni priznao odgovornost ustaša katolika za počinjena zlodjela i teške ljudske tragedije, ustanak koji je izbio i poremećene društvene odnose u kotarevima Bosanske krajine. $^{60}$

\footnotetext{
${ }^{60}$ Kako u hrvatskim, tako i u srpskim krugovima muslimanske rezolucije su imale izrazito negativan odjek, barem ako je suditi po reakciji jedne četničke komande na pismo opskurne „Narodne muslimanske organizacije“ koja je odgovorila na optužbe u četničkoj Poruci Muslimanima Bosne - ukazujući na to da su muslimanski uglednici jasno izrazili svoj odnos prema NDH i ustaškim zločinima putem rezolucija koje su potpisivane u svim većim gradovima. Omalovažavajući rezolucije, četnička komanda je odgovorila: „Platonske rezolucije muslimanske inteligencije nisu donele u praksi ništa. One mogu da posluže kao lepi, istoriski dokumenti, ali bez rezultata. Trebalo je više raditi, a manje pisati.“ Potpisnici nisu imali hrabrosti upustiti se u pravu borbu, pa su radije izabrali „jalove rezolucije“. Vidjeti: GHB, ZRDA, A-810/B. ONS, II knjiga. Jedna od četničkih komanda. Izvršnom odboru Narodne muslimanske organizacije za Bosnu i Hercegovinu. Nedatirano. Ovaj je komentar, dakako, odražavao prvobitni odnos četničkog pokreta prema Bošnjacima, obilježen masovnim zločinima koji su pravdani „odmazdom“ za zločine ustaša nad srpskim narodom u prvim mjesecima NDH. No, dvije godine kasnije, kada su četnici pokušavali uključiti Bošnjake u borbu za obnovu Jugoslavije na monarhističkim osnovama, u Poruci đenerala Draže Mihailovića muslimanima širom Jugoslavije iz 1944, muslimanske rezolucije su pomirljivo spomenute kao primjeri „svesti i građanske hrabrosti“, ali je dodato da su one, usljed ustaške politike koja je imala računa da se muslimani i pravoslavni međusobno bore do istrebljenja, u konačnici ipak ostale „glas vapijućeg“. Jahić, Vrijeme izazova, 474-475.
} 


\section{Ocjene}

Za razliku od dijela historijske literature i publicistike, kritička historiografija je iznijela rezerve u pogledu pozadine, svrhe i značenja muslimanskih rezolucija 1941. Branko Petranović je primijetio da je rezolucija „El-Hidaje“ od 14. augusta 1941. „šovinistički žalila samo za muslimanskim žrtvama ne spominjući srpske “. ${ }^{61}$ Robert J. Donia je podsjetio na to da su „historičari iz ere socijalizma“ istakli da su potpisnici rezolucija kritizirali zločine kao devijantne ekscese, ali nisu napadali ključni ustaški program nasilne fizičke eliminacije određenih grupa. Dodao je da oni, ipak, jesu pozvali vlasti NDH da uspostave red i spriječe daljnje nasilje. ${ }^{62}$ Tomislav Dulić je pisao da se muslimanski uglednici nisu tako snažno suprotstavljali mjerama diskriminacije kao ubistvima. Tokom ljeta 1941. potpisnici rezolucije u Banjoj Luci nisu pozivali na vraćanje imovine Srbima, niti na njihovo ponovno postavljanje na administrativne položaje. Niko od potpisnika nije digao glas protiv rasnih zakona i drugih antijevrejskih mjera. Kada je riječ o mjerama diskriminacije protiv Srba, muslimanski uglednici zauzeli su slično stajalište kao većina Nijemaca prema mjerama eliminacije Jevreja iz javnih službi i drugim ograničenjima njihovih prava. Oni, ipak, nisu prihvatali ubijanja i prisilne konverzije, dijelom iz razloga vlastitih interesa, a dijelom zbog toga što su masovna ubistva koja su se dešavala pred njihovim očima vrijeđala njihov moralni osjećaj. Dulić je primijetio tendenciju potpisnika da individualiziraju zločine pripadnika vlastite etničke grupe, dok su grijesi „drugog“ predstavljani kao kolektivna krivnja i odgovornost. ${ }^{63}$ Slične poglede iznijela je i Emily Greble. Ne može se previdjeti da je većina potpisnika sarajevske rezolucije podržavala njemačku i ustašku agendu prethodnih mjeseci. Makar su sada propovijedali protiv religijske netolerancije, dvanaest potpisnika su također potpisali i antisemitsku

\footnotetext{
${ }^{61}$ Branko Petranović, Revolucija i kontrarevolucija u Jugoslaviji (1941-1945), knjiga prva (Beograd: Izdavačka radna organizacija „Rad“, 1983), 95.

${ }^{62}$ Robert J. Donia, Sarajevo: biografija grada (Sarajevo: Institut za istoriju, 2006), 214.

${ }^{63}$ Dulić, Utopias of Nation, 232-235.
} 
peticiju da se „zaustave Jevreji“ u martu 1941. Bilo je kritike, ali ne i protesta protiv diskriminacije i deportacija Jevreja. Sarajevsku rezoluciju treba razumjeti kao proizvod situacije. Bio je to direktan odgovor na radikalizaciju ustaške politike, koja se osjetila diljem muslimanske zajednice, kao i na podređeni položaj muslimana u NDH. Pokušaj da se ospori ustaški način vladanja, no ne i pokušaj da se zaustavi genocid. ${ }^{64}$ Zlatko Hasanbegović je dodatno skrenuo pažnju na potrebu sagledavanja političko-društvenog konteksta donošenja pojedinih rezolucija. Prema njegovom mišljenju, za pravilno valoriziranje rezolucija važno je imati uvid u to da se njihovo donošenje događalo u vremenu kada je u NDH dolazilo do popuštanja „revolucionarne stihije“ te postepene promjene politike državne represije prema nepoćudnim narodima i zajednicama. ${ }^{65}$

Pri ocjeni muslimanskih rezolucija 1941. važno je ostati u okvirima historije balkanskih naroda prve polovine XX stoljeća i ne zanemariti modele kolektivnog rasuđivanja i djelovanja njihovih elita. Iskustva prve Jugoslavije pokazala su šta je konfesionalno obojen nacionalizam uradio ideji južnoslavenskog zajedništva. Ova realnost je bila uslovljena naslijeđenim društvenim i političkim barijerama. Kako je pisao Ivo Banac, ni austrougarski ni osmanski ni postosmanski obrazac državništva nisu poticali razvitak pluralističke političke kulture, a još manje kulturu prilagođavanja. ${ }^{66}$ Zapravo je kultura vlastitosti određivala forme i domete kolektivne svijesti i društvene akcije. Potpisnike rezolucija 1941. valjalo bi posmatrati kao pripadnike jednog skučenog, slabašnog i uznemirenog naroda, više puta šokiranog iznenadnim historijskim zapletima i zaokretima, a ne kao borce za univerzalna ljudska prava, koja su u njihovo vrijeme, čak i u politički mnogo razvijenijim društvima, bila $\mathrm{u}$ najbolju ruku tek jedan magloviti ideal. $U$ tom smislu ne iznenađuje izostanak osude protujevrejskih mjera i „šovinističko“ žaljenje samo za ${ }^{64}$ Emily Greble, Sarajevo 1941-1945. Muslims, Christians, and Jews in Hitler's Europe (Ithaca - London: Cornell University Press, 2011), 126-127.

${ }^{65}$ Hasanbegović, „Muslimanske rezolucije“, 171-172.

${ }^{66}$ Ivo Banac, Nacionalno pitanje u Jugoslaviji. Porijeklo, povijest, politika (Zagreb: Globus, 1988), 385. 
muslimanskim žrtvama. Da li je u zatvorenim i nedemokratskim društvima tog vremena moglo biti drugačije? Usto, jesu li potpisnici rezolucija mogli znati da neće snositi posljedice za svoje potpise? U NDH su ubijani posve nedužni ljudi - ko je jamčio potpisnicima da neće potpasti pod tačke 1. i 2. Zakonske odredbe za obranu naroda i države koje su nalagale smrtnu kaznu za svakoga ko na bilo koji način „povrijedi ili je povrijedio čast i životne interese hrvatskog naroda ili na bilo koji način ugrozi opstanak Nezavisne Države Hrvatske ili državne vlasti, pa makar djelo ostalo samo u pokušaju“? ${ }^{67}$ Nezadovoljni položajem svojih sunarodnjaka u Kraljevini Jugoslaviji, mnogi bošnjački uglednici su u razbijanju Jugoslavije i nastanku NDH vidjeli dugo priželjkivani nagovještaj boljeg vremena - makar nauštrb interesa drugih naroda i zajednica. No, to nije podrazumijevalo odsustvo osjećaja za pravdu i ignoriranje prava „drugog“. Fehim Spaho je i prije i za vrijeme NDH više puta urgirao u korist pripadnika drugih naroda i vjera. Nema razloga misliti da su se pripadnici visoke uleme rukovodili drukčijim moralnim normama u odnosu prema inovjercima. Među potpisnicima rezolucija je bilo muslimana koji su više bili po volji bivšeg režima nego vlastite zajednice. No, u vremenu o kojem pišemo (pitanje je da li je danas puno drukčije) elite su se smatrale pozvanim istupati i zalagati se prije svega za interese vlastitog naroda i zajednice, etničke, političke ili vjerske grupe, smatrajući da se ima ko starati za prava „drugog“, zaokupljene mišlju da je već učinjeno „dovoljno“ nepravde prema „nama i našima“ i da je krajnje vrijeme da se stave u prvi plan njihove potrebe i interesi. Navedeno bi moglo objasniti zašto su, nakon kritike protusrpskih demonstracija i poziva na dobrosusjedstvo, izostale u godinama Velikog rata reakcije katoličkih i muslimanskih vjerskih prvaka na represivne mjere austrougarskog režima prema pripadnicima srpske zajednice. Kao što pomaže razumijevanju potpunog muka srpske političke, intelektualne

${ }^{67}$ Nezavisna Država Hrvatska. Zakoni, zakonske odredbe, naredbe i t. d. proglašene od 11. travnja do 26. svibnja 1941, Knjiga I, (svezak 1.-10.), ur. A. Mataić (Zagreb: Knjižare St. Kugli, 1941). Zakonska odredba za obranu naroda i države od 17. travnja 1941. 
i vjerske elite na vijesti o teroru i ubistvima muslimanskih žitelja Podrinja, istočne Hercegovine i Sandžaka u prvim godinama Kraljevine SHS. Vidjeli smo kako su neki katolički krugovi reagirali na navode $\mathrm{u}$ rezolucijama. Ne samo da je izostala osjetljivost na patnju običnog čovjeka nego je zanemareno i stradanje pripadnika čitave grupe. Tomislav Dulić je postavio pitanje zašto Katolička crkva u NDH nije istupila sa protestom poput rezolucija muslimanskih intelektualaca u Bosni i Hercegovini. Nadbiskup Alojzije Stepinac jeste, ističe Dulić, intervenirao u korist pojedinaca i manjih grupa ljudi, ali to nikada nije zadobilo formu otvorene i organizirane kampanje širom zemlje, dok su u isto vrijeme katolički klerici zdušno učestvovali u prisilnim konverzijama. Situacija nije bila ništa bolja ni sa pravoslavne strane. Srpska pravoslavna crkva suzdržala se od bilo kakvog protesta protiv četničkih zločina. Dulić je iznio mišljenje da su mnogi pravoslavni i katolički svećenici uložili isuviše mnogo u izgradnju nove države (Jugoslavije i NDH) da bi je otvoreno kritizirali i napadali. Sa muslimanima to nije bio slučaj, zbog marginalizacije u društvu ustaške države, neovisno o stvarnim namjerama režima prema islamu i muslimanima. ${ }^{68}$ Ipak, zaključimo, bez obzira na to koliko su smisao i vrijednost muslimanskih rezolucija bili relativizirani užim staleškim i etničkim interesima njihovih potpisnika, te nespremnošću da se glavnim osudama dā najšire građansko značenje, ovi odvažni društveni akti nesporno ostaju svijetao primjer hrabrosti i odgovornosti konkretnih ljudi koji su založili svoja imena i integritet za jedan novi poredak u kojem ne bi carovali opasna krvava anarhija i vjerska i nacionalna mržnja i isključivost. 


\section{IZVORI I LITERATURA}

\section{IZVORI}

\section{Neobjavljeni izvori:}

- Arhiv Bosne i Hercegovine, Sarajevo (ABiH)

- Fond: Zemaljska komisija za utvrđivanje zločina okupatora i njihovih pomagača Sarajevo (ZKURZ)

- Zbirka NOR-a (NOR)

- Arhiv Tuzlanskog kantona, Tuzla (ATKT):

- Zbirka: Radnički pokret i NOB u sjeveroistočnoj Bosni 1920. - 1945. (RP-NOB)

- Zbirka: Ustaška nadzorna služba (UNS)

- Gazi Husrev-begova biblioteka, Sarajevo (GHB), Arhiv Islamske zajednice:

- Fond: Ulema-medžlis

- Zbirka: Povjerljiva arhivska građa (POV)

- Zbirka rasutih dokumenata i arhivalija na bosanskom jeziku (ZRDA)

- Historijski arhiv Sarajevo, Sarajevo (HAS):

- Zbirka: Fehim Spaho (FS)

- Hrvatski državni arhiv, Zagreb (HDA):

- Fond: Ministarstvo unutarnjih poslova Nezavisne Države Hrvatske (MUP NDH, HR-HDA-223)

- Fond: Odjeljenje zaštite naroda za Hrvatsku (OZNA, HR-HDA-1491)

- Fond: Služba državne sigurnosti Republičkog sekretarijata unutarnjih poslova Socijalističke Republike Hrvatske (SDS RSUP SRH, HR-HDA-1561)

- Fond: Velika župa Posavje (VŽP, HR-HDA-254) 
- Zbirka mikrofilmova gradiva iz inozemnih arhiva koje se odnosi na Hrvatsku (ZMGIA-H, HR-HDA-1450)

- Institut za historiju u Sarajevu, Sarajevo (IHS):

- Arhivska građa (AG), kut. 65

- Vojni arhiv, Beograd (VA):

- Fond: Nezavisna Država Hrvatska (NDH)

\section{Objavljeni izvori:}

- Boban, Ljubo. Hrvatska u arhivima izbjegličke vlade 1941-1943. Izvještaji informatora o prilikama u Hrvatskoj. Zagreb: Globus, 1985.

- Dedijer, Vladimir - Miletić, Antun. Proterivanje Srba sa ognjišta 1941-1944. Beograd: Prosveta, 1989.

- Mataić, A. (ur.) Nezavisna Država Hrvatska. Zakoni, zakonske odredbe, naredbe i t. d. proglašene od 11. travnja do 26. svibnja 1941. Knjiga I. (svezak 1.-10.). Zagreb: Knjižare St. Kugli, 1941.

- Vukčević, Slavko (ur.) Zločini na jugoslovenskim prostorima u Prvom i Drugom svetskom ratu. Zbornik dokumenata, tom I, Zločini Nezavisne Države Hrvatske 1941.-1945. Beograd: Vojnoistorijski institut, 1993.

- Zbornik dokumenata i podataka o narodnooslobodilačkom ratu jugoslovenskih naroda, tom IV, knjiga 1. Beograd: Vojnoistorijski institut JNA, 1951.

\section{Štampa:}

- Hrvatski narod, Zagreb, 1941.

\section{LITERATURA}

\section{Knjige:}

- Adamović, Vedrana. Godine stradanja 1941/42. NDH i njeni zločini nad srpskim narodom u Prijedoru i okolini 1941/42. (Prilog proučavanju 
zločina genocida nad srpskim narodom u Potkozarju). Prijedor: Muzej Kozare, 2018.

- Banac, Ivo. Nacionalno pitanje u Jugoslaviji. Porijeklo, povijest, politika. Zagreb: Globus, 1988.

- Bulajić, Milan. Ustaški zločini genocida i suđenje Andriji Artukoviću 1986. godine, I. Beograd: Izdavačka radna organizacija „Rad“, 1988.

- Donia, Robert J. Sarajevo: biografija grada. Sarajevo: Institut za istoriju, 2006.

- Dulić, Tomislav. Utopias of Nation. Local Mass Killing in Bosnia and Herzegovina, 1941-42. Uppsala: Uppsala University Library, 2005.

- Đurić, Ljuban. Banijski partizanski odredi 41-45. Beograd: Vojnoizdavački i novinski centar, 1988.

- Greble, Emily. Sarajevo, 1941-1945. Muslims, Christians, and Jews in Hitler's Europe. Ithaca - London: Cornell University Press, 2011.

- Hadžijahić, Muhamed. Posebnost Bosne i Hercegovine i stradanja Muslimana. Rukopis dostavljen savezničkim snagama 1944. Sarajevo: Centar za bosansko-muslimanske studije, 1991.

- Hasanbegović, Zlatko. Jugoslavenska muslimanska organizacija 1929. - 1941. (u ratu i revoluciji 1941. - 1945.). Zagreb: Bošnjačka nacionalna zajednica za Grad Zagreb i Zagrebačku županiju - Institut društvenih znanosti Ivo Pilar - Medžlis Islamske zajednice Zagreb, 2012.

- Jahić, Adnan. Vrijeme izazova. Bošnjaci u prvoj polovini XX stoljeća. Zagreb - Sarajevo: Bošnjačka nacionalna zajednica za Grad Zagreb i Zagrebačku županiju - Bošnjački institut - Fondacija Adila Zulfikarpašića, 2014.

- Jaskić, Safet. Srbokomunistički zločin nad Bosnom, reprint izdanje. Tuzla: Izdavačko prometno preduzeće „Hamidović“” 2003.

- Kisić Kolanović, Nada. Muslimani i hrvatski nacionalizam 1941. 1945. Zagreb: Školska knjiga - Hrvatski institut za povijest, 2009. 
- Krišto, Jure. Sukob simbola. Politika, vjere i ideologije u Nezavisnoj Državi Hrvatskoj. Zagreb: Nakladni zavod Globus, 2001.

- Pervan, Tahir. Nad jamom. Sarajevo: Safe House, 2010.

- Petranović, Branko. Revolucija i kontrarevolucija u Jugoslaviji (19411945), knjiga prva. Beograd: Izdavačka radna organizacija „Rad“, 1983.

- Redžić, Enver. Bosna i Hercegovina u Drugom svjetskom ratu. Sarajevo: OKO, 1998.

- Spomenica poginulim Bilećanima u NOR i revoluciji. Bileća: Opštinski odbor SUBNOR-a Bileće, 1983.

\section{Članci:}

- Čaušević, Izudin. „Ustaška vlast i teror na Kozari 1941-1942 godine“, u: Kozara u Narodnooslobodilačkoj borbi i socijalističkoj revoluciji (1941-1945). Radovi sa naučnog skupa održanog na Kozari (Mrakovica) 27. i 28. oktobra 1977. godine u okviru proslave Titovih jubileja i 35-godišnjice kozarske epopeje, ur. Nikola Babić. Prijedor: Nacionalni park „Kozara“, 1980, 101-122.

- Dobrača, Kasim. „Rad Handžića u El-Hidaji i njegov družtveni rad uobće“. El-Hidaje VIII, br. 2-3 (1944): 82-88.

- Hadžijahić, Muhamed. „Muslimanske rezolucije iz 1941. godine“, u: 1941. u istoriji naroda Bosne i Hercegovine, Sarajevo: Veselin Masleša, 1973, 275-282.

- Hamzić, Omer. „Podsjećanje na dvije muslimanske rezolucije iz 1941. godine - bijeljinsku i tuzlansku“. Gračanički glasnik, br. 34 (2012): 110-117.

- Hasanbegović, Zlatko. „Muslimanske rezolucije iz 1941. godine. Problem interpretacije“. Bošnjačka pismohrana. Zbornik radova XIX simpozija „Bošnjačko iskustvo antifašizma“ 12, br. 36-37 (2013): 165-175.

- „Izvještaj Uglješe Danilovića Tempu“. Vojnoistorijski glasnik, br. 4 (1951): 179-186. (ćir.) 
- Jahić, Adnan. „Bilješke o djelovanju bosanskohercegovačke uleme u Drugom svjetskom ratu“. Historijska misao, br. 1 (2015): 181-206.

- Jahić, Adnan. „Zbivanja u Bosni i Hercegovini 1941. godine prema Hronici Mustafe Mulalića“, u: Bosna i Hercegovina 1941: novi pogledi, ur. Husnija Kamberović. Sarajevo: Institut za istoriju, 2012, 169- 185.

- Popadić, Branko. „Na prostoru Stoca i Bileće“, u: Hercegovina u NOB, 2, ur. Sveto Kovačević. Beograd: Vojnoizdavački i novinski centar - Beograd - Istorijski arhiv Hercegovine - Mostar, 1986, 631-650.

- Vukmanović, Milan. „Okupacija i uspostavljanje ustaške vlasti na području Bosanske krajine i Srednje Bosne u prvim mjesecima 1941. godine“, u: Oblasna partijska savjetovanja na Šehitlucima u junu i julu 1941. u razvoju ustanka u Bosanskoj krajini. Banja Luka: Institut za istoriju u Banjaluci, 1981, 57-98.

- Zatezalo, Đuro. „Razvoj i rad KPJ i organa narodne vlasti. Čerkezovački partizanski odred“, u: Dvor na Uni. Od prijeslavenskog doba do naših dana, knj. 1, ur. Mile Joka. Dvor na Uni: Skupština Općine Dvor na Uni, 1991, 297-323. (ćir.)

- Zulfikarpašić, Adil. „Put u Foču. 25. I. 1942. godine“. Godišnjak, br. 4 (1957): 44-55. 


\section{Summary}

\section{The Muslim Resolutions of 1941. On the occasion of 80 years since their signing}

In this paper, the author tries to shed light on the broader background of the Muslim resolutions of 1941, analyzes their content, makes questions about the credibility and sustainability of some of their claims and assesments, deals with the told and unspoken matters in their messages, and portrays the contested views and controversies that have been following the appearance of the Muslim resolutions to the present day. The author points out the importance, when evaluating the Muslim resolutions of 1941, to stay within the history of the Balkan nations of the first half of the 20th century and not to neglect the models of collective reasoning and actions of their elites. The experiences of the first Yugoslavia showed what confessionally colored nationalism did to the idea of the South Slavic unity. In the Balkans, the culture of oneness has determined the forms and domains of collective consciousness and social action. The signatories to the 1941 Muslim resolutions should be seen primarily as individuals belonging to a cramped, weak and restless people, repeatedly shocked by sudden historical incidents and upheavals, rather than as fighters for universal human rights, which in their time, even in politically much more developed societies, were in most cases just one hazy ideal. However, no matter how much the meaning and value of Muslim resolutions were relativized by the narrower class and ethnic interests of their signatories, and by their unwillingness to give the broadest civic meaning to their main condemnations, these bold social acts have undoubtedly remained a shining example of the courage and responsibility of specific people who pledged their names and integrity for a new order which would not be dominated by dangerous bloody anarchy and religious and national hatred and exclusivity. 